\title{
Effectiveness of Mechanically Tenderized Beef Labels on Influencing Practices of Cooking Beef in British Columbia
}

\author{
Arunjit Heran ${ }^{1}$, Bobby Sidhu
}

\begin{abstract}
1. Lead Author, B. Sc., Simon Fraser University, B. Tech Student, School of Health Sciences, British Columbia Institute of Technology, 3700 Willingdon Avenue, Burnaby, BC V5G 3H2
\end{abstract}

2. Supervisor, School of Health Sciences, British Columbia Institute of Technology, 3700 Willingdon Avenue, Burnaby, BC V5G 3H2 


\begin{abstract}
Background: Mechanically tenderized beef poses a higher risk for Escherichia coli 0157:H7 infection than intact beef and has been implicated in several outbreaks. As such, all products are mandated to be labeled in Canada.
\end{abstract}

Purpose: This study assessed the effectiveness of mechanically tenderized beef labels on influencing practices of cooking beef in British Columbia.

Methods: 74 adults within British Columbia who cooked beef were surveyed electronically using a snowball method. An inferential (Pearson chi-square analysis) and descriptive analysis was performed on the nominal data in PSPP and Microsoft Excel respectively.

Results: Only 8\% of respondents abided with information on mechanically tenderized beef labels. No statistically significant associations were found between practices of abiding with information on mechanically tenderized beef labels and various socio-demographic factors (e.g. age, gender, education level, and food safety education) ( $\mathrm{p}<0.01)$. The practice of not using food thermometers was the major contributing factor that lowered the effectiveness of mechanically tenderized beef labels.

Conclusion: Mechanically tenderized beef labels were ineffective in influencing behaviours of cooking beef in British Columbia. Therefore, other risk communication strategies are needed to persuade adults in British Columbia to adequately cook mechanically tenderized beef products.

Recommendations: Future studies can assess whether the general public is properly cooling mechanically tenderized beef as the label does not address this practice.

Key words: Mechanically tenderized beef; Escherichia coli 0157:H7; Label, Risk communication. 


\section{Table of Contents}

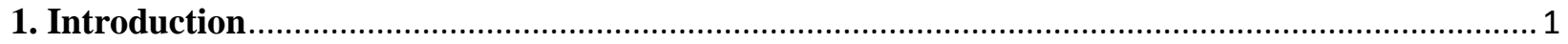

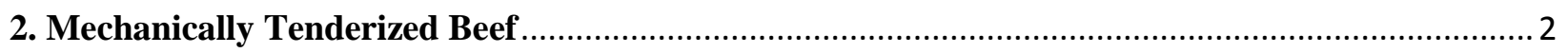

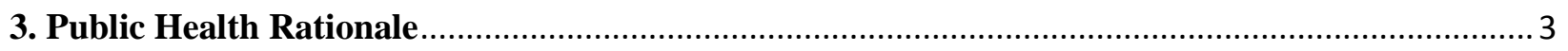

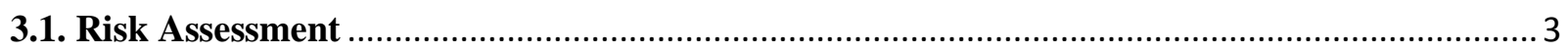

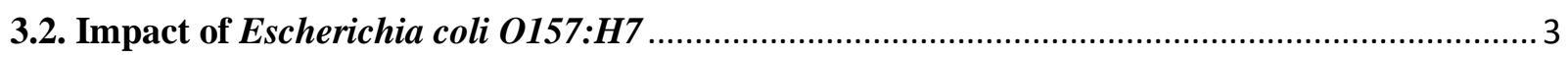

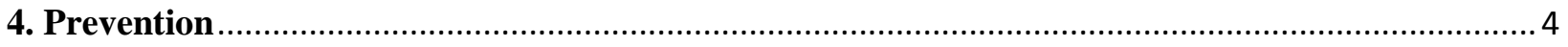

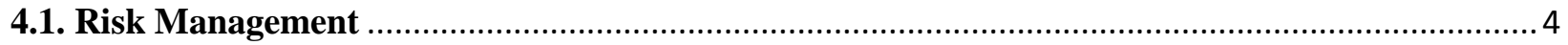

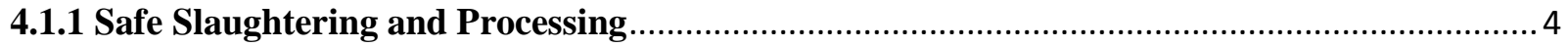

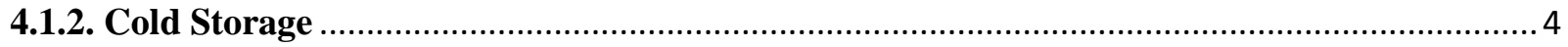

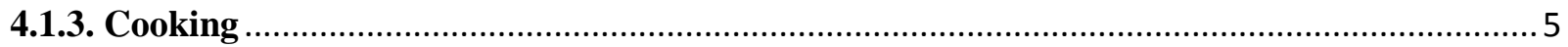

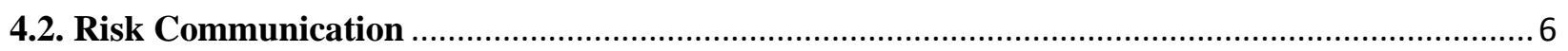

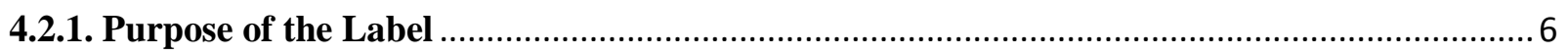

4.2.2. Legislative Requirement for Labeling ........................................................................ 6

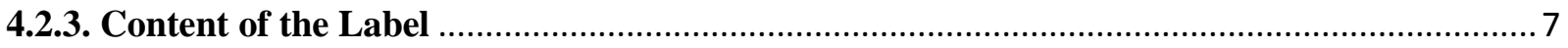

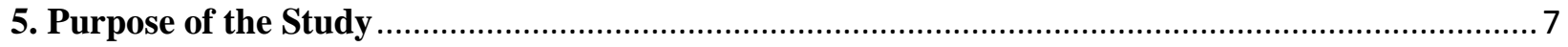

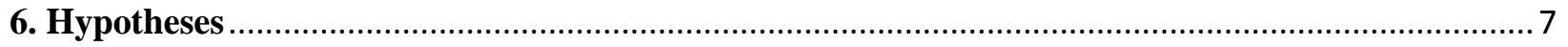

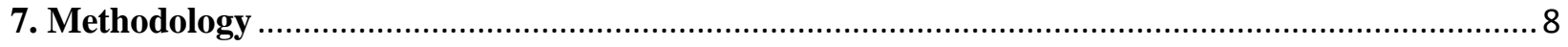

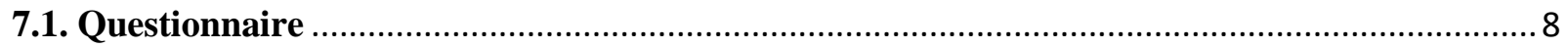

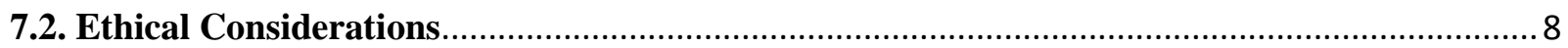

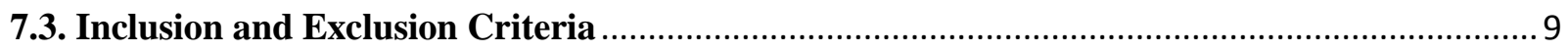

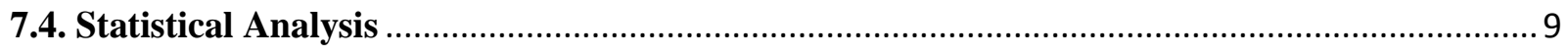

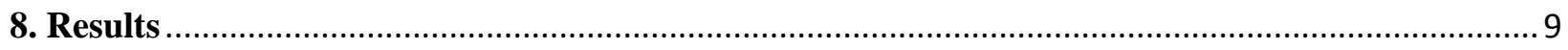

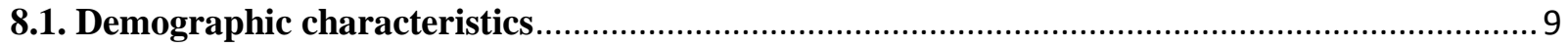

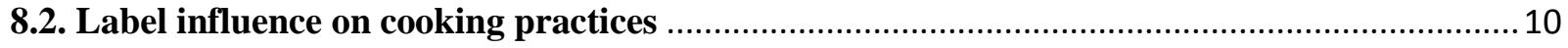

8.3. Association between demographic factors and label effectiveness ...................................... 10

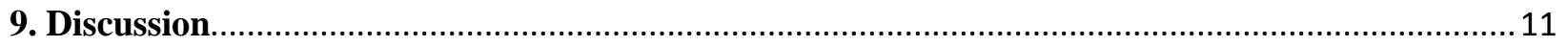

9.1. Effectiveness of Mechanically Tenderized Beef Labels ................................................... 11

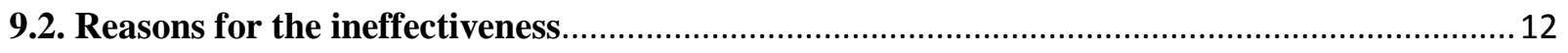

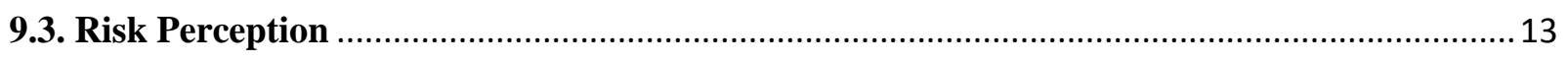

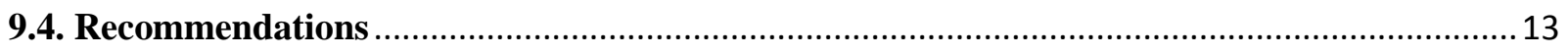

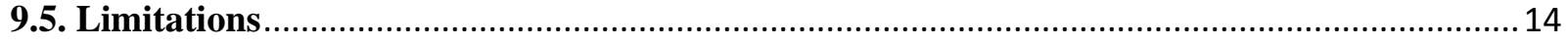

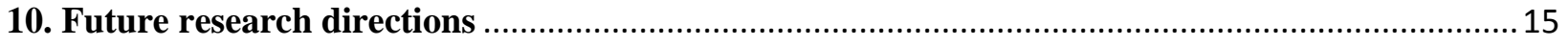




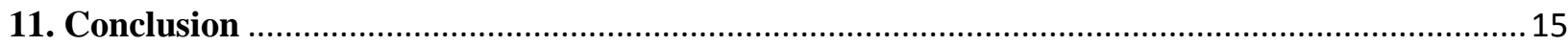

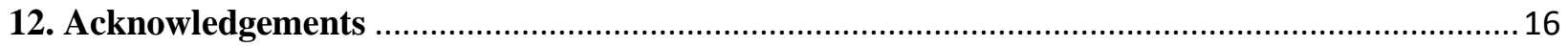

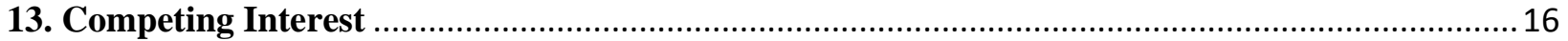

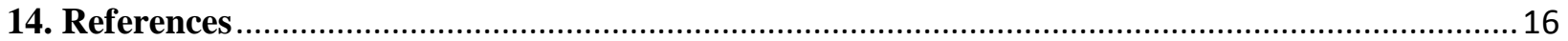

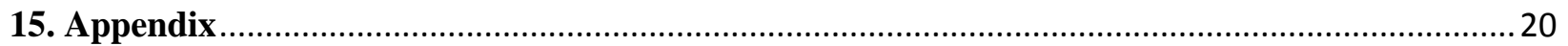

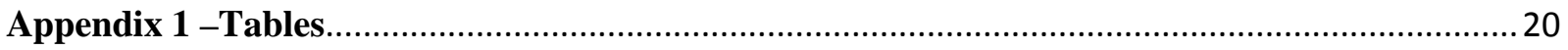

Table 1: Outbreaks in North America between the years 2000 and 2012 pertaining to mechanically

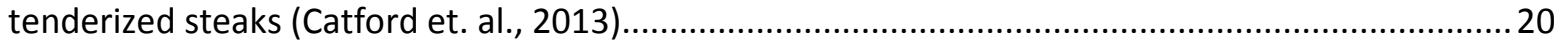

Table 2: Deaths pertaining to Pathogenic Escherichia coli infection in Canada between the years 2000 to 2004 based on CIHI and Vital Statistics (Government of Canada, 2013). ...........................20

Table 3: Incidence Rates of Escherichia Coli 0157 per 100,000 population in Canada reported to NESP between the years 2007 to 2013 (Public Health Agency of Canada, 2014)............................ 21

Table 4: Null hypotheses with respect to certain variables ........................................................... 21

Table 5: Alternate hypotheses with respect to certain variables ................................................... 22

Table 6: Materials required with respect the study methodology .................................................. 22

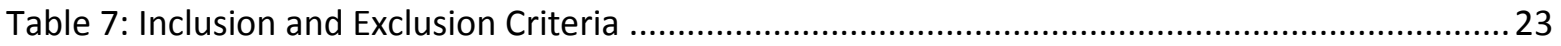

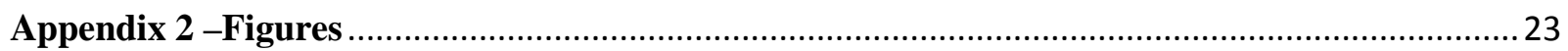

Figure 1: Incidence rate of Escherichia coli 0157 VTEC and Escherichia coli serotypes per 100,000 population in Canada between the years 2003 to 2013 reported to NESP (Public Health Agency of

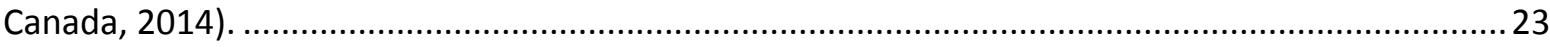

Figure 2: Label on Packaged Mechanically Tenderized Beef (Health Canada, 2014) ....................... 24

Figure 3: Percentage of participants by age group in $\mathrm{BC}, 2015(\mathrm{~N}=74)$......................................... 24

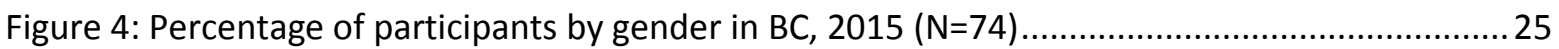

Figure 5: Percentage of participants by highest level of education in $B C, 2015(\mathrm{~N}=74)$.................. 25

Figure 6: Percentage of participants by successful completion of a food safety course in BC, 2015

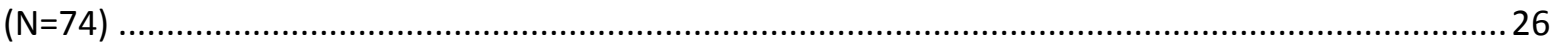

Figure 7: Percentage of participants by awareness of health risk associated with mechanically

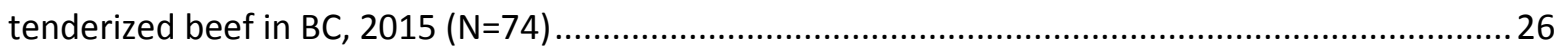

Figure 8: Percentage of participants willing to purchase mechanically tenderized beef in BC, 2015 $(\mathrm{N}=74)$

Figure 9: Percentage of participants by cooking practices in abiding with information on mechanically tenderized beef labels in $B C, 2015(N=74)$.

Figure 10: Percentage of cooking practices that abide with information provided on mechanically tenderized beef labels in BC, 2015 ( $N=74)$

Figure 11: Percentage of cooking practices that involve flipping steak at least twice in accordance with mechanically tenderized beef labels in BC, $2015(\mathrm{~N}=69)$ 
Figure 12: Percentage of participants by preferred method of receiving cooking information ........ 29

Figure 13: Percentage of respondents by preference of beef doneness ......................................... 29

Figure 14: Association between age and label effectiveness in BC, $2015(\mathrm{~N}=72)$.......................... 30

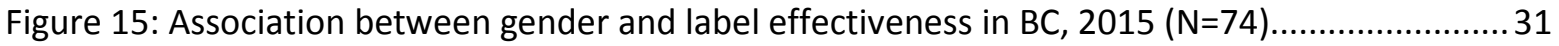

Figure 16: Association between highest level of education and label effectiveness in BC, 2015 $(\mathrm{N}=74)$

Figure 17: Association between successful completion of a food safety course and label effectiveness in BC, 2015 ( $N=74)$ 33

Figure 18: Association between awareness of risk associated with mechanically tenderized beef and label effectiveness in BC, $2015(\mathrm{~N}=74)$

Figure 19: Association between preferred method of receiving cooking information and label effectiveness in BC, 2015 ( $N=72)$ 35

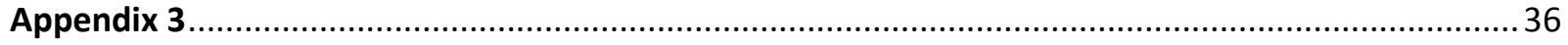

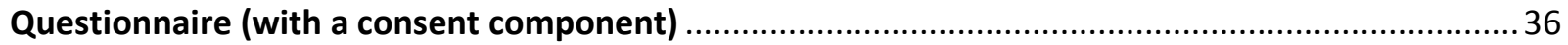




\section{Introduction}

Securing food safety remains an issue of public health significance as there are approximately 4 million foodborne illnesses per year in Canada (Public Health Agency of Canada, 2014). Several Escherichia coli O157 outbreaks pertaining to mechanically tenderized beef have occurred from 2000 to 2012 in North America (Table 1 in Appnedix 1) (Catford et. al., 2013). Recently in 2012, XL Foods Inc. was responsible for 18 cases of E. coli O15:H7 illness in Brooks, Alberta, some of which were associated with consumption of mechanically tenderized beef (Government of Canada, 2013).

The incidence rate of E. coli O157:H7 infection in Canada, 2013 was 1.34 cases per 100,000 population (Table 3 in Appendix 1) (Public Health Agency of Canada, 2014). When considering under-reporting issues whereby an estimated 347 gastrointestinal illnesses actually occur for every reported case in British Columbia, the actual incidence rate may be higher (MacDougall, 2008). The relatively low incidence rate of E. coli O157:H7 nonetheless reaffirms the strength of the Food Safety System in Canada and the important role of the various parties involved (Figure 1 in Appendix 2; Government of Canada, 2013). This includes the role of the Public Health Agency of Canada in national enteric disease surveillance, Agriculture and AgriFood Canada in development of food safety policies for farmers, and Health Canada in performing risk assessments (Government of Canada, 2013). It also includes the role of the Canadian Food Inspection Agency in initiating recalls of contaminated beef, Public Health Inspectors in mitigating health hazards in food service establishments, and meat processors in diligently following good manufacturing practices (Government of Canada, 2013). However, mechanical tenderization still increases risk of E. coli O157 infection despite the efforts of these parties.

Mechanical tenderization of beef increases the relative risk of $E$. coli O157:H7 infection by 5 times compared to non-mechanically tenderized beef (Catford et. al., 2013). This is due to E. coli O157:H7 being transmitted to the interior of the mechanically tenderized beef, which can remain undercooked (Catford et. al., 2013). E. coli O157:H7 endangers public health due to its low infectious dose and potential severe health effects (Gill et. al., 2013). For these reasons, the implementation of control measures (e.g. adequately cooking mechanically tenderized beef to 
inactivate E. coli O157:H7) is crucial in protecting public health (Gill et. al., 2013; Gill \& McGinnis, 2004). This will further strengthen the Food Safety System in Canada.

Even more, communicating knowledge about these control measures to domestic consumers is imperative. One method is through labeling mechanically tenderized beef products with the proper cooking instructions for inactivating E. coli O157:H7. Such labeling is mandated under the Regulations Amending the Food and Drug Regulations since August 21, 2014 (Canada Gazette, 2014). Although mandated, little is still known about the effectiveness of information on mechanically tenderized beef labels on influencing practices of cooking beef. Therefore, this study will examine this issue in the context of risk communication.

\section{Mechanically Tenderized Beef}

The meat industry is driven to produce tender beef since it is a higher quality product that is associated with increased sales revenues (Montgomery \& Leheska, 2008; Miller et al., 2001). There are several limiting factors (e.g. stress in cattle prior to slaughter) that hinder the production of tender beef. To overcome such hurdles, the meat industry uses chemical and mechanical methods to enhance meat tenderness. Amongst the various methods, mechanical tenderization is of interest to this study.

Mechanical tenderization is a process of tenderizing meat by disrupting its muscle fibers and connective tissue with instruments (e.g. needles or blades), or by injecting it with a tenderizing or marinade solution (Canada Gazette, 2014). It is performed by processors, retailers, and consumers (Gill et al., 2013). Mechanically tenderized beef is produced by nearly 78 of 815 registered meat establishments and constitutes about 20-37\% of beef products in Canada (Canada Gazette, 2014). Although these products are economically beneficial, they pose public health repercussions that must be managed. 


\section{Public Health Rationale}

\subsection{Risk Assessment}

Based on a risk assessment conducted by Health Canada, mechanically tenderized beef had a five-time higher relative risk than intact beef in causing E. coli 0157 illness (Catford et. al.,2013). This is because cattle contain E. coli O157:H7 and E. coli O157:NM on their hide and inside their intestines (Kiranmayi et. al., 2010). Mechanical tenderizers can transfer this pathogen both vertically (i.e. from the surface of the contaminated beef to the interior) and horizontally (i.e. from one cut of beef to another via cross-contamination) (Catford et. al., 2013; Luchansky et. al., 2008).

Vertical transmission is of concern as it cannot be controlled by good manufacturing practices and implementation of a sanitation plan (Catford et. al., 2013). Furthermore as a consumer is unable to physically distinguish mechanically tenderized beef from intact beef, they may not take the precautionary measures of cooking this meat thoroughly to an internal temperature of $63^{\circ} \mathrm{C}$ (Health Canada, 2014). As a result, the pathogen in the interior of the contaminated beef may survive the cooking process (Gill et. al., 2013). This increases the risk of E. coli O157:H7 and/or E. coli O157:NM infection (Gill et. al., 2013).

Currently, there is no data on the dose response relationship for E. coli O157:H7 from consumption of mechanically tenderized beef (Catford et. al., 2013). However studies on ground beef and salami products suggest that a small infectious dose of 10 cells can potentially cause toxicoinfection (Catford et. al., 2013).

\subsection{Impact of Escherichia coli O157:H7}

E. coli O157:H7 can cause foodborne illness via Shiga toxin 1 and/or Shiga toxin 2 (Kiranmayi et. al., 2010). Complications include gastrointestinal symptoms, bloody and nonbloody diarrhea, hemorrhagic colitis (HC), haemolytic uremic syndrome (HUS), and Thrombocytic Thrombocytopaenic Purpura (TTP) (Kiranmayi et. al., 2010). Those most vulnerable include children, the elderly, pregnant women, and immunocompromised individuals (Kiranmayi et. al., 2010; Catford et. al., 2013). In severe cases, death may result. The mean 
mortality rate of pathogenic E. coli was 1.80 per 1,000 cases from 2000 to 2004 (Table 2 in Appendix 1) (Government of Canada, 2013).

The economic sector is impacted negatively as well. Hospitalizations add financial burden on the healthcare system with EHEC 0157 being the fourth most expensive foodborne illness in North America (Kiranmayi et. al., 2010; Public Health Agency of Canada, 2014). Media alerts about contaminated beef recalls (e.g. XL Foods Inc.) undermine trust in the Food Safety System of Canada (Government of Canada, 2013). This reduces consumption of beef products and purchases from large processing plants (Government of Canada, 2013). Finally, beef recalls and closures of meat processing plants result in financial losses for both meat processors and their suppliers (e.g. farmers) (Government of Canada, 2013). Therefore, prevention of E. coli O157:H7 infection is warranted.

\section{Prevention}

\subsection{Risk Management}

\subsubsection{Safe Slaughtering and Processing}

Ante-mortem and post-mortem inspections during the slaughter and processing stages help prevent diseased cattle from being processed for human consumption (Canadian Food Inspection Agency, 2014). Abattoirs and processors of raw beef are required to implement a Hazard Analysis Critical Control Points (HACCP) plan which manages the risk of E. coli O157:H7 infection (e.g. reduces cross-contamination) (Canadian Food Inspection Agency, 2014). Although these practices reduce the likelihood of contaminated beef reaching consumers, they do not eliminate the risk. Therefore, further controls are needed to prevent E. coli O157:H7 infection.

\subsubsection{Cold Storage}

Mechanically tenderized beef is a potentially hazardous food since it has internal conditions (i.e. slight acidity, adequate moisture, and high protein content) for supporting the growth of infectious and/or toxigenic microorganisms (CFISIG, 2004). Growth of E. coli 
O157:H7 in mechanically tenderized beef has been observed at incubation temperatures of 10 , $15,20,25$, and $37^{\circ} \mathrm{C}$ (Huang, 2010). This is consistent with the finding that growth of many pathogens occurs between $4^{\circ} \mathrm{C}$ and $60^{\circ} \mathrm{C}$ for potentially hazardous food (CFISIG, 2004). At $5^{\circ} \mathrm{C}$, no growth of E. coli O157:H7 was observed, which may be attributed to competitive exclusion (Huang, 2010). Therefore, mechanically tenderized beef should be kept refrigerated at $4^{\circ} \mathrm{C}$ or less during cold storage (CFISIG, 2004). In addition, leftovers should be cooled from $60^{\circ} \mathrm{C}$ to $20^{\circ} \mathrm{C}$ within 2 hours and from $20^{\circ} \mathrm{C}$ to $4^{\circ} \mathrm{C}$ within 4 hours for slowing growth of pathogens (CFISIG, 2004).

However refrigerated temperatures do not inactivate $E$. coli $0157: H 7$. Some cells of $E$. coli O157:H7 were found to survive in mechanically tenderized beef kept at $5^{\circ} \mathrm{C}$ over s 25 day observation period (Huang, 2010). This indicates that a critical control step beyond refrigeration (i.e. a final lethal heat step) is needed for destroying E. coli O157:H7 in mechanically tenderized beef.

\subsubsection{Cooking}

Mechanically tenderized beef should be cooked adequately and thoroughly to inactivate E. coli O157:H7. Studies suggest that cooking it to internal temperatures of $63^{\circ} \mathrm{C}, 65.4^{\circ} \mathrm{C}$, and $73.4^{\circ} \mathrm{C}$ is sufficient for inactivating E. coli O157:H7 (Gill and McGinnis, 2004; Gill et. al., 2005). This finding is consistent with the recommended temperature for rare roast beefs proposed by the Canadian Retail and Food Services Code (CFISIG, 2004). Mechanically tenderized beef steaks should also be turned over at least twice during the cooking process to allow heat to evenly penetrate through and inactivate E. coli O157:H7 (Gill et. al., 2013).

However, food handlers may be unaware of this knowledge and therefore undercook mechanically tenderized beef. Hence, informing food handlers about this knowledge is crucial. One method of communicating it to them is through labeling mechanically tenderized beef with the pertinent cooking instructions. 


\subsection{Risk Communication}

\subsubsection{Purpose of the Label}

Labeling informs the general public that beef has undergone a mechanical tenderization process which requires specific cooking instructions (Government of Canada, 2013). Adherence with these cooking instructions should lead to an inactivation of E. coli O157:H7 in contaminated mechanically tenderized beef products (Government of Canada, 2013). This in turn should reduce the occurrence of E. coli O157:H7 infections in Canada (Government of Canada, 2013). Subsequently, fewer illnesses, hospitalizations, and deaths from this infection should result. The expenditure costs on the healthcare system should be also be reduced.

\subsubsection{Legislative Requirement for Labeling}

Mandatory labeling of mechanically tenderized beef was proposed in Canada, 2013 under the Safe Food for Canadians Action Plan (Canada Gazette, 2014). Subsequently, the Meat Hygiene Manual of Procedures (MOP) was amended under the Meat Inspection Regulations, which mandated labeling for federal processors (Canada Gazette, 2014). Then as of August 21, 2014, the Regulations Amending the Food and Drug Regulations came into force (Health Canada, 2014). This amendment mandates that federal establishments label mechanically tenderized beef that is solid, fresh, frozen, packaged, or non-packaged with the exception of comminuted beef (Canada Gazette, 2014).

This regulation applies to grocery retailers, butcher shop operators, meat processors, and importers (Health Canada, 2014). Food service establishment operators however do not have to label mechanically tenderized beef on their menus (Health Canada, 2014). This may be due to them being mandated to follow the provisions of the BC Food Premises Regulation, which would ensure that they safely handle and prepare potentially hazardous food (Queens’ Printer, 2013). Overall, mechanically tenderized beef products sold in Canada must be labeled by law (Canada Gazette, 2014). 


\subsubsection{Content of the Label}

The label on the principal display panel of prepackaged mechanically tenderized beef must include three legible statements in English and French: "mechanically tenderized”, "Cook to a minimum internal temperature of $63^{\circ} \mathrm{C}\left(145^{\circ} \mathrm{F}\right)$ " and "Turn steak over at least twice during cooking” (Canada Gazette, 2014; Health Canada, 2014) (Figure 2, Appendix 2). The cooking information provided by these statements is congruent with the aforementioned research findings by Gill et. al. (2013) and Gill \& McGinnis (2004). As such, these cooking instructions will likely result in the inactivation of E. coli O157:H7 in mechanically tenderized beef.

Non-packaged mechanically tenderized beef only requires to be identified as such through the statement "mechanically tenderized", which can be placed either on label or on a display sign (Health Canada, 2014).

\section{Purpose of the Study}

The aforementioned literature supports the need for informing the general public about control measures for preventing E. coli O157:H7 illness from mechanically tenderized beef. The Canadian government has decided that labeling mechanically tenderized beef products is an effective way of achieving this. However, little is still known about the effectiveness of mechanically tenderized beef labels in convincing the public to abide with their cooking instructions. Therefore, this study assessed whether information on mechanically tenderized beef labels influences practices of cooking beef in British Columbia, Canada. The assessment involved testing several hypotheses.

\section{Hypotheses}

The null and alternate hypotheses tested by this study are provided in Tables 4 and 5 (Appendix 1). The null hypothesis states that there is no association between practices of abiding with information on mechanically tenderized beef labels and one of the following variables: age, gender, education level, completion of a food safety course, awareness of risk associated with mechanically tenderized beef, and preferred method of receiving cooking information. Whereas, the alternate hypothesis states that there is an association between practices of abiding with 
information on mechanically tenderized beef labels and one of the following variables: age, gender, education level, completion of a food safety course, awareness of risk associated with mechanically tenderized beef, and preferred method of receiving cooking information.

\section{Methodology}

\subsection{Questionnaire}

A 13 question survey was relied on to systematically collect data from participants for testing the hypotheses of the study (Appendix 3). The questionnaire was generated in google docs using the Regulations Amending the Food and Drug Regulations (Mechanically Tenderized Beef) from Canada Gazette as a standard. It was pilot tested by the research supervisor and a layperson. Administration of the survey was conducted through a snowball method whereby initially contacted individuals were asked to further email it to others in chain-like manner. Contacted persons were reminded to partake in the survey through a follow-up email. Materials pertaining to the generation and administration of the survey as well as the analysis of the data are provided in Table 6 (Appendix 1).

\subsection{Ethical Considerations}

The study was reviewed by the Environmental Health Department of the British Columbia Institute of Technology for ethical approval. It met ethical considerations via an informed consent form and a standard cover letter. These forms were based on Health Canada's recommendations for informed consent form requirements (Health Canada, 2014). They guaranteed anonymity, confidentiality, beneficence and autonomy (BCIT, 2013). In addition, the cover letter disclosed the study purpose, methodology, use of data, and potential risks and benefits associated with participation. The consent form confirmed that respondents understood study objectives, methods, duration, voluntary nature, and potential risks and benefits associated with the study. Consent was obtained through a required component embedded within the survey, in which respondents agreed to voluntarily participate (Appendix 3). 


\subsection{Inclusion and Exclusion Criteria}

Study participants included residents of British Columbia who cooked beef and were above 18 years of age (Table 7, Appendix 1). Non-residents of British Columbia were excluded in order to minimize confounding factors amongst the respondents. Individuals who do not cook beef were excluded since their responses would be invalid in assessing the research question. Persons under 18 years were excluded due to ethical considerations, namely the need for gaining parental permission (Table 7, Appendix 1).

\subsection{Statistical Analysis}

The nominal data was analyzed both descriptively and inferentially. It was categorized in Microsoft Excel and conditionally formatted. Missing data was removed from the analysis, percentages of various data categories (e.g. age, gender, and education level) were expressed, and pi-charts were generated using Excel.

A Pearson Chi-Square analysis was performed on the coded data in a statistical software program, PSPP, to test the hypotheses of this study. The data was put into contingency tables by PSPP. Statistical significance of the Pearson Chi-Square Value was assessed at the $95 \%$ confidence level $(\mathrm{p}=0.05)$. The null hypothesis was rejected if the results were statistically significant $(\mathrm{p}<0.05)$ and were not prone to alpha error $(\mathrm{p}<0.01)$. And conversely, the null hypothesis was not rejected when the results were not statistically significant ( $>0.05$ ) and/or when alpha error was present.

\section{Results}

\subsection{Demographic characteristics}

The study involved 74 respondents with varying demographic characteristics. Age varied amongst the respondents with $54 \%$ being between 18 -30 years, $8 \%$ between $31-40$ years, $12 \%$ between $41-50$ years, 23\% above 50 years, and 3\% preferring not to disclose their age (Figure 3, Appendix 2). Males and females comprised the sample size relatively to an equal extent (54\% female and 46\% male) (Figure 4, Appendix 2). The sample consisted mainly of educated 
individuals as $84 \%$ of respondents had at least attained some post-secondary education (Figure 5, Appendix 2). 45\% of respondents had successfully completed a food safety course whereas 55\% did not (Figure 6, Appendix 2). Only 42\% of the respondents were aware of a health risk being associated with mechanically tenderized beef (Figure 7, Appendix 2). Finally, 39\% reported that they were willing to purchase mechanically tenderized beef and 51\% reported that they would not be willing to purchase this type of beef (Figure 8, Appendix 2).

\subsection{Label influence on cooking practices}

The majority of respondents (92\%) reported practices of cooking beef that opposed information provided on mechanically tenderized beef labels whereas $8 \%$ completely complied (Figure 9, Appendix 2). The study found partial abidance with labeling instructions as 33\% of respondents reported that they read labels on beef packaging, 28\% affirmed they follow cooking instructions on beef labels, 31\% preferred their beef "well-done” or “medium-done”, and 8\% checked the temperature of beef using a thermometer (Figure 10, Appendix 2). Of the 69 respondents who cook steak, 77\% reported flipping the steak at least twice during the cooking process and 11\% preferred their steak cooked to a rare condition (Figure 11 and 13, Appendix 2).

A label was preferred by $46 \%$ of 72 respondents as a method of receiving cooking information on beef (Figure 12, Appendix 2). The remaining respondents preferred other methods of receiving cooking information: 20\% preferred the "in person” option (e.g. from a butcher or a health expert), 20\% preferred a recipe, $8 \%$ preferring a television show, and 6\% preferring other means (e.g. the news, a magazine, a brochure, and the internet) (Figure 12, Appendix 2).

\subsection{Association between demographic factors and label effectiveness}

No statistically significant association was found between practices of abiding with information on mechanically tenderized beef labels and any of the following factors: age, gender, education level, completion of a food safety course, awareness of risk associated with mechanically tenderized beef, and preferred method of receiving cooking information on beef ( $\mathrm{p}=0.097,0.288,0.016,0.151,0.675$, and 0.831 respectively) (Figures 14-19, Appendix 2). As 
the p-values were not less than 0.05 and/or alpha error may be evident, it was likely that the results were due to chance and the null hypotheses were not rejected (Table 4, Appendix 1).

\section{Discussion}

\subsection{Effectiveness of Mechanically Tenderized Beef Labels}

This study found that $92 \%$ of respondents were not abiding with information on mechanically tenderized beef labels. This indicates that mechanically tenderized beef labels were ineffective in influencing practices of cooking beef in British Columbia. This finding is congruent with the results of other studies on the usage of food labels. For example, a study revealed that only $26 \%$ of American respondents $(n=2797)$ completely used food labels (Chen et. al., 2012). Another study found that nutritional label use varied amongst American respondents with only $61.6 \%$ using the Nutrition Facts Panel and 43.8\% paying attention to health claims (Ollberding et. al., 2011). These studies however report a higher usage of food labels than the current study. This may be attributed to the public being less familiar with mechanically tenderized beef labels than nutrition labels as they were mandated only recently in 2014 .

This study found no statistically significant associations between practices of following mechanically tenderized beef labels and the following variables: age, gender, education level, completion of a food safety course, awareness of risk associated with mechanically tenderized beef, and preferred method of receiving cooking information on beef. This finding however is inconsistent with literature as other studies on food labels report statistically significant associations between food label use and demographic factors (e.g. age, gender, and health-related variables such as nutrition knowledge) (Stran and Knol, 2013; Hess et. al, 2011). However when accounting for variations in nationality and label type amongst literature, the finding of the current study may still be valid. Hence despite the socio-demographic factors assessed by this study, the population of British Columbia at large is at risk by not abiding with mechanically tenderized beef labels.

Interestingly, socio-demographic factors and health-related variables that were not assessed by the current study have been shown to be significant determinants of food label use. For example, socio-economic status, geographic region, race, weight, attitude, knowledge, trust in label content and design, motivating factors and other health-related factors have been found 
to be significantly associated with label use (Chen et. al, 2012; Hall and Osses, 2013; Hess et. al., 2011). This suggests that other socio-demographic factors and motivations (e.g. health consciousness) may potentially be associated with the use of mechanically tenderized beef labels.

\subsection{Reasons for the ineffectiveness}

The major behavioural factor that lowered the effectiveness of mechanically tenderized beef labels was the lack of food thermometer use by $92 \%$ of the respondents. This finding is consistent with current literature. A study found that $82 \%$ of respondents who owned food thermometers used them for roasts while 23\% used them for hamburgers in $2010(\mathrm{p}<0.05)$ (Lando et. al., 2012). It revealed that the use of thermometers varied with food type and ownership. Similarly, another study found that only 14\% of Canadian respondents used thermometers to determine meat doneness whereas the majority relied on visual cues, time, taste, and other methods (Nesbitt et. al., 2014). Two other studies found that $81 \%$, 86\%, and $82 \%$ of respondents never used food thermometers when cooking ground beef, hamburgers, and when reheating leftovers respectively (Nesbitt et. al., 2014). Reasons for the low use of food thermometers may include that they are inconvenient and difficult to use (Shapiro et. al., 2011). In addition, a culture non-supportive of food thermometers can also contribute to the lack of thermometer use. For example, cooking shows tend to encourage using meat colour as a determinant of doneness as opposed to internal temperature (Shapiro et. al., 2011).

A less significant factor that lowered the effectiveness of mechanically tenderized beef labels was $23 \%$ of respondents failing to turn beef over at least twice when cooking it. This may be due to the majority of respondents (91\% of them) preferring non-rare steak, which could be due to a number of reasons. For example, they may not find differences in beef quality (i.e. tenderness, juiciness, or flavour) when steaks are cooked to different conditions of doneness (O’Quinn, 2015). Hence, they may not mind turning it over frequently and cooking it to a "welldone” state.

Finally, the effectiveness of mechanically tenderized beef labels was reduced due to practices of not reading labels and not following labeling instructions by $67 \%$ and $72 \%$ of the respondents respectively. As previously mentioned, these findings are supported by current 
literature on food labels. Interestingly, even educated consumers (i.e. 84\% with at least some post-secondary education) with a food safety background (i.e. $45 \%$ with a food safety course) were not abiding with mechanically tenderized beef label information. Hence, there seems to be a discrepancy between knowledge of food safety and food handling behaviour. Furthermore, it appears that knowledge of food safety is insufficient in encouraging people to abide with information on mechanically tenderized beef labels. Reasons for this may be attributed to risk perception.

\subsection{Risk Perception}

It seems that consumers perceive risk separately from experts based on their psychological processes rather than technical knowledge (Verbeke et. al., 2006). In fact, even many of the $42 \%$ of respondents who were aware of a health risk being associated with mechanically tenderized beef were not abiding with information on labels. Hall and Osses (2013) explain that consumers disregard cooking instructions if they are confident about their skills and knowledge of food safety. In addition, consumers base their risk perception on factors related to outrage, such their trust in authorities (Sandman, 1993). Given the relatively low percentage of participants aware of a health risk being associated with mechanically tenderized beef (including the XL Foods Outbreak in 2012), it seems there is less outrage in Canada pertaining to mechanically tenderized beef. Hence, risk perception of mechanically tenderized beef amongst British Columbia's population seems to be low. For these reasons, this study recommends increasing awareness of risk associated with mechanically tenderized beef to enable Canadians to perceive it more seriously. This may promote safer practices of cooking beef, such as abiding with label information. Overall, eliciting behaviour change in consumers is needed, which involves evaluating individual behaviours and targeting their specific needs (Verbeke et. al., 2006).

\subsection{Recommendations}

Food safety messages can be effectively communicated to consumers if they are sent through the consumer's preferred source of food safety information (Nesbitt et. al., 2014). This study found that $54 \%$ of 72 respondents preferred sources of food safety information other than labels (e.g. in person, recipe, television show, news, magazines, brochures, and the internet). 
Similarly, another study found that food labels, the internet, and magazines/newspapers were more commonly used by Canadian respondents as sources of nutritional information (Goodman et. al., 2011). Therefore, this study recommends that risk communication about mechanically tenderized beef be conducted through a variety of media to accommodate the unique preferences of consumers.

Food thermometer use should also be promoted as a lack of its use was a major contributing factor in lowering the effectiveness of mechanically tenderized beef labels. Shapiro et. al. (2011) support that the practice of cooking foods to adequate internal temperatures should be promoted in educational materials, cookbooks, magazines, newspapers, and on cooking shows. This will enable cultural change to occur which supports the use of food thermometers. Furthermore, establishing a new cultural norm may help consumers make behavioural changes in favour of using food thermometers.

This study also recommends that food safety courses be taught in both a persuasive and informative manner since knowledge solely is insufficient in eliciting behaviour change. For example, this study found that awareness of a risk being associated with mechanically tenderized beef was insufficient in persuading most of the $42 \%$ respondents to follow label instructions. Shapiro et. al. (2011) recommend that food safety messages incorporate a component of social desirability since subjective norms (e.g. social pressure) affect food handling practices. Hence, food safety educators (e.g. Public Health Inspectors) should stress the use of food thermometers in the context of thermometers being socially desirable and expected by consumers rather than focusing solely on their scientific relevance. This may help re-shape the cultural norm toward one that socially pressures society to use food thermometers. Finally, Public Health Inspectors involved in health promotion and the healthy communities approach should encourage decision makers to promote a pro-thermometer culture for securing food safety.

\subsection{Limitations}

There were several limitations to the current study. The survey design may have introduced self-report bias. The inclusion criteria limited valid extrapolation of the results to adults in British Columbia who cook beef. This study only assessed current behavioural practices of abiding with mechanically tenderized beef labels rather than a change in behavioural practices 
upon the Regulations Amending the Food and Drug Regulations coming into force. Another study has likewise found an increase in nutritional label use upon the implementation of new Food and Administration Regulations (Kristal et. al., 1998). The current study also did not evaluate the partial effectiveness of mechanically tenderized beef labels on cooking behaviours. Finally, this study did not test associations between practices of abiding with mechanically tenderized beef labels and the following socio-demographic factors: income, profession, race, health status, health consciousness, and ethnicity. Testing such associations may have been beneficial in identifying a target group for food safety interventions.

\section{Future research directions}

Future studies can assess the impact of mechanically tenderized beef labels on practices of cooking beef in other Canadian provinces and over time. They can assess associations between mechanically tenderized beef labels and socio-economic factors (e.g. income and health consciousness) that were not assessed by the current study. This may help identify a target group for food safety interventions.

Alternatively, future studies may assess other behavioural food safety practices (e.g. cooling of mechanically tenderized beef leftovers) that are not addressed by the label. They can also assess the effect of label design in influencing practices of using mechanically tenderized beef labels. Finally, practices of cooking various types of mechanically tenderized meat (e.g. poultry and pork) may be evaluated to determine whether new policies, regulations, and/or other public health interventions are needed for them.

\section{Conclusion}

Mechanically tenderized beef labels serve an informative role in providing consumers with information that will enable them to make more informed choices and adequately cook beef. However, they do not fulfill a persuasive function in effectively influencing cooking practices of beef. As they do not elicit behaviour change for most people, food safety interventions are recommended for specifically targeting the food safety needs of the public in British Columbia (e.g. increasing food thermometer use). In addition, risk communication through a variety of media (e.g. recipes, television, new, and online) is strongly recommended 
for informing the public of the importance of adequately cooking mechanically tenderized beef. Together these measures will further secure food safety in British Columbia, Canada.

\section{Acknowledgements}

The author of this study would like to thank Bobby Sidhu, researcher supervisor, for providing support and constructive feedback throughout the research paper.

\section{Competing Interest}

The author declares that they do not have a competing interest.

\section{References}

Canada Gazette. (2014). Regulations Amending the Food and Drug Regulations (Mechanically Tenderized Beef). Retrieved from: http://canadagazette.gc.ca/rp-pr/p2/2014/2014-0521/html/sor-dors99-eng.php

Canadian Food Inspection Agency. (2014). Chapter 17 -Ante and Post-mortem Procedures, Dispositions, Monitoring and Controls -Meat Species, Ostriches, Rheas, and Emus. Retrieved from: http://www.inspection.gc.ca/food/meat-and-poultry-products/manual-ofprocedures/chapter-17/eng/1367723343665/1367723573062

Canadian Food Inspection System Implementation Group (CFISIG). (2004). Food Retail and Food Services Code. Retrieved from: http://foodsafe.ca/resources/Food_Services_Code2004.pdf

Catford, A., Lavoie, M. C., Smith, B., Buenaventura, E., Couture, H., Fazil, A., \& Farber, J. M. (2013). Findings of the health risk assessment of Escherichia coli 0157 in mechanically tenderized beef products in Canada. International Food Risk Analysis Journal, 3 (3), 1-12.

Chen, X., Jahns, L., Gittelsohn, J., \& Wang, Y. (2012). Who is missing the message? Targeting strategies to increase food label use among US adults.Public health nutrition, 15(05), 760772. 
Gill, C. O., \& McGinnis, J. C. (2004). Microbiological conditions of mechanically tenderized beef cuts prepared at four retail stores. International journal of food microbiology, 95(1), 95-102.

Gill, C.O., McGinnis, J.C., Young, D., Lee, N. \& Barbut, S. (2005). Microbiological condition of beef mechanically tenderized at a packing plant. Meat Science, 69, 811-816.

Gill, C.O., Yang, X. Uttaro, B., Badoni, M, \& Liu, T. (2013). Effects of Survival of Escherichia coli 0157:H7 in Non-Intact Steaks of the Frequency of Turning Over Steaks During Grilling. Journal of Food Research, 2 (5), 77-89.

Goodman, S., Hammond, D., Pillo-Blocka, F., Glanville, T., \& Jenkins, R. (2011). Use of nutritional information in Canada: national trends between 2004 and 2008. Journal of nutrition education and behavior, 43(5), 356-365.

Government of Canada. (2013). Food Safety: Independent Review of XL Foods Inc. Beef Recall 2012. Retrieved from: http://www.foodsafety.gc.ca/english/xl_reprt-rapprte.asp

Hall, C., \& Osses, F. (2013). A review to inform understanding of the use of food safety messages on food labels. International Journal of Consumer Studies, 37(4), 422-432.

Health Canada. (2014). Guidance on Mandatory Labelling for Mechanically Tenderized Beef. Retrieved from: http://www.hc-sc.gc.ca/fn-an/legislation/guide-ld/mech-tenderized-beefboeuf-attendris-meca-eng.php

Health Canada. (2014). Requirements for Informed Consent Documents. Retrieved from: http://www.hc-sc.gc.ca/sr-sr/advice-avis/reb-cer/consent/index-eng.php

Hess, R., Visschers, V. H., \& Siegrist, M. (2011). The role of health-related, motivational and sociodemographic aspects in predicting food label use: a comprehensive study. Public health nutrition, 15(03), 407-414.

Huang, L. (2010). Growth kinetics of Escherichia coli 0157:H7 in mechanically-tenderized beef. International Journal of Food Microbiology, 140(1), 40-48. 
Kiranmayi, C. B., Krishnaiah, N., \& Mallika, E. N. (2010). Escherichia coli O157: H7-An Emerging pathogen in foods of animal origin. Veterinary World, 3(8), 382-389.

Kristal, A., Levy, L., Patterson, S., Li, S., and White, E. (1998). Trends in food label use associated with new nutrition labeling regulations. American Journal of Public Health, 88, (8), 1212-1215.

Lando, A. M., \& Chen, C. C. (2012). Trends in ownership and usage of food thermometers in the United States, 1998 through 2010. Journal of Food Protection ${ }^{\circledR}, 75(3), 556-562$.

Luchansky, J. B., Phebus, R. K., Thippareddi, H., \& Call, A. (2008). Translocation of surfaceinoculated Escherichia coli O157: H7 into beef subprimals following blade tenderization. Journal of Food Protection ${ }^{\circledR}, 71(11), 2190-2197$.

MacDougall, L., Majowicz, S., Dore, K., Flint, J., Thomas, K., Kovacs, S., \& Sockett, P. (2008). Under-reporting of infectious gastrointestinal illness in British Columbia, Canada: who is counted in provincial communicable disease statistics?. Epidemiology and infection, 136(02), 248-256.

Miller, M. F., Carr, M. A., Ramsey, C. B., Crockett, K. L., \& Hoover, L. C. (2001). Consumer thresholds for establishing the value of beef tenderness. Journal of Animal Science, 79(12), 3062-3068.

Montgomery, T., \& Leheska, J. (2008). Effect of Various Management Practices on Beef-Eating Quality. Retrieved from: http://www.sustainablebeef.org/_assets/SBRC-Beef-EatingQuality.pdf

Nesbitt, A., Thomas, M. K., Marshall, B., Snedeker, K., Meleta, K., Watson, B., \& Bienefeld, M. (2014). Baseline for consumer food safety knowledge and behaviour in Canada. Food Control, 38, 157-173.

Ollberding, N. J., Wolf, R. L., \& Contento, I. (2011). Food label use and its relation to dietary intake among US adults. Journal of the American Dietetic Association, 111(5), 47-51. 
O'Quinn, T. G., Brooks, J. C., \& Miller, M. F. (2015). Consumer Assessment of Beef Tenderloin Steaks from Various USDA Quality Grades at 3 Degrees of Doneness. Journal of food science.

Public Health Agency of Canada. (2014). E. coli. Retrieved from: http://www.phacaspc.gc.ca/fs-sa/fs-fi/ecoli-eng.php

Public Health Agency of Canada. (2014). Estimates of Food-borne Illness in Canada. Retrieved from: http://www.phac-aspc.gc.ca/efwd-emoha/efbi-emoa-eng.php

Public Health Agency of Canada. (2009). Hospitalizations, Deaths, and Unusual Isolation Sites. Retrieved from: http://www.phac-aspc.gc.ca/publicat/ccdrrmtc/09vol35/35s3/hospitalizations-hospitalisations-eng.php

Queen’s Printer. (2013). Public Health Act Food Premises Regulation. B.C. Reg. 210/99 o.c. 774/99. Retrieved from: http://www.bclaws.ca/Recon/document/ID/freeside/11_210_99

Sandman, P. (1993). Agency Communication, Community, Outrage, and Perception of Risk: Three Simulation Experiments. Risk Analysis, 13 (6), 585-598.

Shapiro, M. A., Porticella, N., Jiang, L. C., \& Gravani, R. B. (2011). Predicting intentions to adopt safe home food handling practices. Applying the theory of planned behavior. Appetite, 56(1), 96-103.

Stran, K. A., \& Knol, L. L. (2013). Determinants of food label use differ by sex. Journal of the Academy of Nutrition and Dietetics, 113(5), 673-679.

The British Columbia Institute of Technology (BCIT). (2013). Guidelines for completing applications for ethical review of activities involving human participants. Retrieved from: http://www.bcit.ca/files/appliedresearch/pdf/rebethics_review_guidelines_form_two.pdf

Verbeke, W., Frewer, L., Scholderer, J., Brabander, H. (2006). Why consumers behave as they do with respect to food safety and risk information. Analytica Chimica Acta. 586: 2-7 


\section{Appendix}

\section{Appendix 1 -Tables}

Table 1: Outbreaks in North America between the years 2000 and 2012 pertaining to mechanically tenderized steaks (Catford et. al., 2013).

\begin{tabular}{|c|l|l|c|l|}
\hline Year & Type of meat & Location & Cases & Publication source \\
\hline 2000 & needle tenderized sirloin steaks & USA & 2 & $\begin{array}{l}\text { USDA-FSIS, 2005 } \\
\text { FR 70:30331-30334 }\end{array}$ \\
\hline 2003 & $\begin{array}{l}\text { boneless beef filet bacon-wrapped steak } \\
\text { product injected with marinade }\end{array}$ & USA & 11 & $\begin{array}{l}\text { Laine et al., 2005 } \\
\text { I. Food Prot. 2005, 68(6):1198 }\end{array}$ \\
\hline 2004 & tenderized, marinated beef steak product & USA & 4 & $\begin{array}{l}\text { USDA-FSIS, 2005 } \\
\text { FR 70:30331-30334 }\end{array}$ \\
\hline 2009 & blade tenderized steaks & USA & 21 & $\begin{array}{l}\text { CDC, 2010 } \\
\text { Published online }\end{array}$ \\
\hline 2012 & needle tenderized steaks & Canada & 5 & $\begin{array}{l}\text { PHAC, 2013 } \\
\text { Internal communications }\end{array}$ \\
\hline
\end{tabular}

Table 2: Deaths pertaining to Pathogenic Escherichia coli infection in Canada between the years 2000 to 2004 based on CIHI and Vital Statistics (Government of Canada, 2013).

\begin{tabular}{|l|l|c|c|c|c|}
\hline & \multicolumn{4}{|c|}{ CIHI Database } & \multicolumn{2}{c|}{ Vital Statistics Database } \\
\hline & Year & $\begin{array}{c}\text { Number } \\
\text { of Deaths } \\
\text { (CIHI) }\end{array}$ & $\begin{array}{c}\text { Death rate (per } \\
\text { 1000 hospitalized } \\
\text { with illness) }\end{array}$ & $\begin{array}{c}\text { Number of } \\
\text { Deaths } \\
\text { (Vital } \\
\text { Stats) }\end{array}$ & $\begin{array}{c}\text { Death Rate } \\
\text { (per 1000 } \\
\text { cases) }\end{array}$ \\
\hline $\begin{array}{l}\text { Pathogenic } \\
\text { E. coli }\end{array}$ & 2000 & 5 & 8.24 & 6 & 1.99 \\
\hline & 2001 & 2 & 4.51 & 1 & 0.75 \\
\hline & 2002 & 6 & 15.67 & 3 & 2.41 \\
\hline & 2003 & 1 & 4.26 & 2 & 1.85 \\
\hline & 2004 & 4 & 12.50 & 1.82 \\
\hline
\end{tabular}


Table 3: Incidence Rates of Escherichia Coli 0157 per 100,000 population in Canada reported to NESP between the years 2007 to 2013 (Public Health Agency of Canada, 2014).

\begin{tabular}{|c|c|c|c|c|c|c|c|c|c|c|c|c|c|c|}
\hline \multirow{2}{*}{ Group } & \multicolumn{2}{|c|}{2007} & \multicolumn{2}{c|}{2008} & \multicolumn{2}{c|}{2009} & \multicolumn{2}{c|}{2010} & \multicolumn{2}{c|}{2011} & \multicolumn{2}{c|}{2012} & \multicolumn{2}{c|}{2013} \\
\cline { 2 - 12 } & Total & Rate & Total & Rate & Total & Rate & Total & Rate & Total & Rate & Total & Rate & Total & Rate \\
\hline $\begin{array}{c}\text { E. coli } \\
\text { O157 } \underline{\underline{\Psi}}\end{array}$ & 934 & 2.84 & 661 & 1.99 & 529 & 1.57 & 405 & 1.19 & 481 & 1.40 & 486 & 1.40 & 470 & 1.34 \\
\hline
\end{tabular}

Table 4: Null hypotheses with respect to certain variables

\begin{tabular}{|l|l|l|}
\hline $\begin{array}{l}\text { Hypothesis } \\
\text { Number }\end{array}$ & Variable & Null Hypotheses \\
\hline H1 & Age & $\begin{array}{l}\text { There is no association between age and practices of abiding } \\
\text { with information on MTB* labels }\end{array}$ \\
\hline H2 & Gender & $\begin{array}{l}\text { There is no association between gender and practices of } \\
\text { abiding with information on MTB* labels }\end{array}$ \\
\hline H3 & Education Level & $\begin{array}{l}\text { There is no association between education level and } \\
\text { practices of abiding with information on MTB* labels }\end{array}$ \\
\hline H4 & $\begin{array}{l}\text { Completion of a Food } \\
\text { Safety Course }\end{array}$ & $\begin{array}{l}\text { There is no association between completion of a food safety } \\
\text { course and practices of abiding with information on MTB* } \\
\text { labels }\end{array}$ \\
\hline H5 & $\begin{array}{l}\text { Risk awareness of } \\
\text { mechanically } \\
\text { tenderized beef }\end{array}$ & $\begin{array}{l}\text { There is no association between awareness of risk } \\
\text { associated with MTB* and practices of abiding with } \\
\text { information on MTB* labels }\end{array}$ \\
\hline H6 & $\begin{array}{l}\text { Preferred method of } \\
\text { receiving cooking } \\
\text { information }\end{array}$ & $\begin{array}{l}\text { There is no association between preferred method of } \\
\text { receiving cooking information on beef and practices of } \\
\text { abiding with information on MTB* labels }\end{array}$ \\
\hline
\end{tabular}

*MTB = mechanically tenderized beef 
Table 5: Alternate hypotheses with respect to certain variables

\begin{tabular}{|l|l|l|}
\hline $\begin{array}{l}\text { Hypothesis } \\
\text { Number }\end{array}$ & Variable & Null Hypotheses \\
\hline H1 & Age & $\begin{array}{l}\text { There is an association between age and practices of } \\
\text { abiding with information on MTB* labels }\end{array}$ \\
\hline H2 & Gender & $\begin{array}{l}\text { There is an association between gender and practices } \\
\text { of abiding with information on MTB* labels }\end{array}$ \\
\hline H3 & Education Level & $\begin{array}{l}\text { There is an association between education level and } \\
\text { practices of abiding with information on MTB* labels }\end{array}$ \\
\hline H4 & $\begin{array}{l}\text { Completion of a } \\
\text { Food Safety Course }\end{array}$ & $\begin{array}{l}\text { There is an association between completion of a food } \\
\text { safety course and practices of abiding with information } \\
\text { on MTB* labels }\end{array}$ \\
\hline H5 & $\begin{array}{l}\text { Risk awareness of } \\
\text { mechanically } \\
\text { tenderized beef }\end{array}$ & $\begin{array}{l}\text { There is an association between awareness of risk } \\
\text { associated with MTB* and practices of abiding with } \\
\text { information on MTB* labels }\end{array}$ \\
\hline H6 & $\begin{array}{l}\text { Preferred method of } \\
\text { receiving cooking } \\
\text { information }\end{array}$ & $\begin{array}{l}\text { There is an association between preferred method of } \\
\text { receiving cooking information on beef and practices of } \\
\text { abiding with information on MTB* labels }\end{array}$ \\
\hline
\end{tabular}

*MTB =Mechanically Tenderized Beef

Table 6: Materials required with respect the study methodology

\begin{tabular}{|c|c|}
\hline Methods & Materials \\
\hline Electronic Survey & $\begin{array}{l}\text { - } \text { Cover letter, consent form, and } \\
\text { - } \text { questionnaire } \\
\text { - } \text { Exoogle docs } \\
\text { - Email (gmail) }\end{array}$ \\
\hline Question content & $\begin{array}{l}\text { - Regulations Amending the Food and } \\
\text { Drug Regulations (Mechanically } \\
\text { Tenderized Beef) }\end{array}$ \\
\hline Statistical analysis & $\begin{array}{ll}\text { - } & \text { PSPP (Chi-Square test) } \\
\text { - } & \text { Microsoft Excel (bar graphs) }\end{array}$ \\
\hline
\end{tabular}


Table 7: Inclusion and Exclusion Criteria

\begin{tabular}{|l|l|}
\hline Inclusion Criteria & Exclusion Criteria \\
\hline Residents of British Columbia & Non-residents of British Columbia \\
\hline People who cook beef & People who do not cook beef \\
\hline People who are 18 years or older & People under the age of 18 years \\
\hline
\end{tabular}

\section{Appendix 2 -Figures}

Figure 1: Incidence rate of Escherichia coli 0157 VTEC and Escherichia coli serotypes per 100,000 population in Canada between the years 2003 to 2013 reported to NESP (Public Health Agency of Canada, 2014).

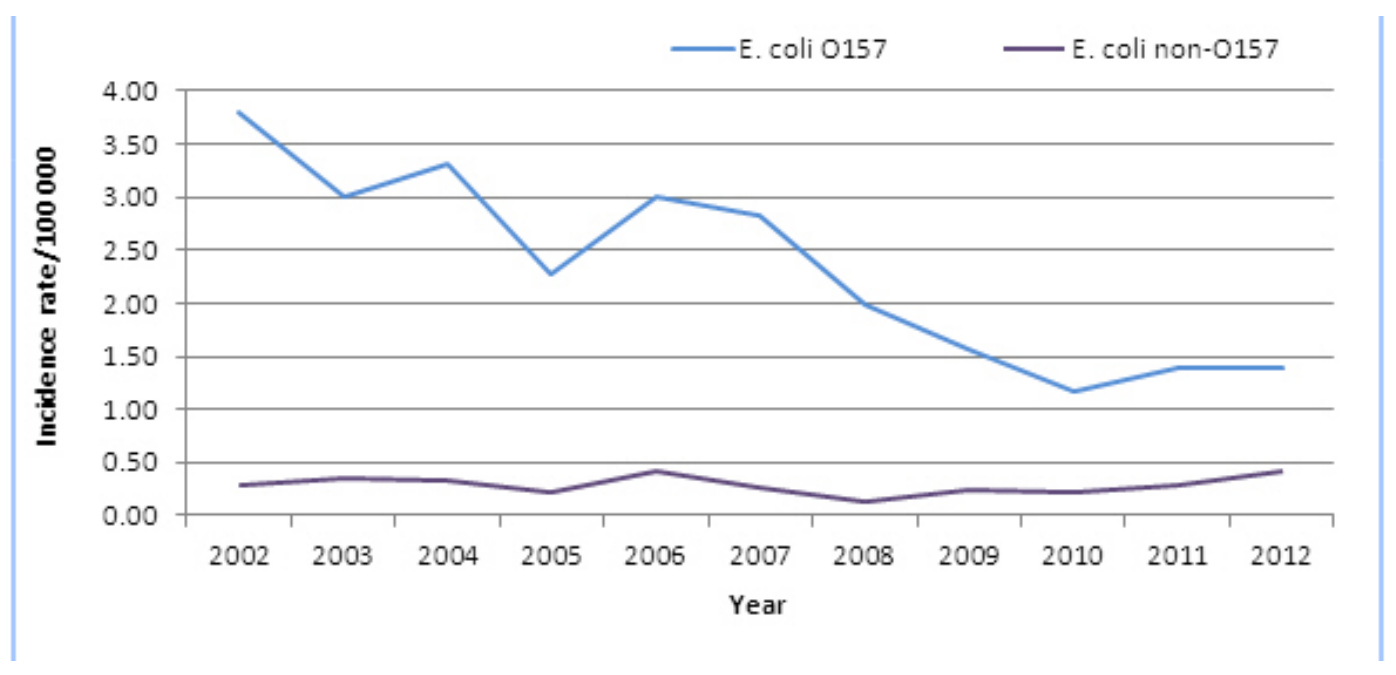


Figure 2: Label on Packaged Mechanically Tenderized Beef (Health Canada, 2014)

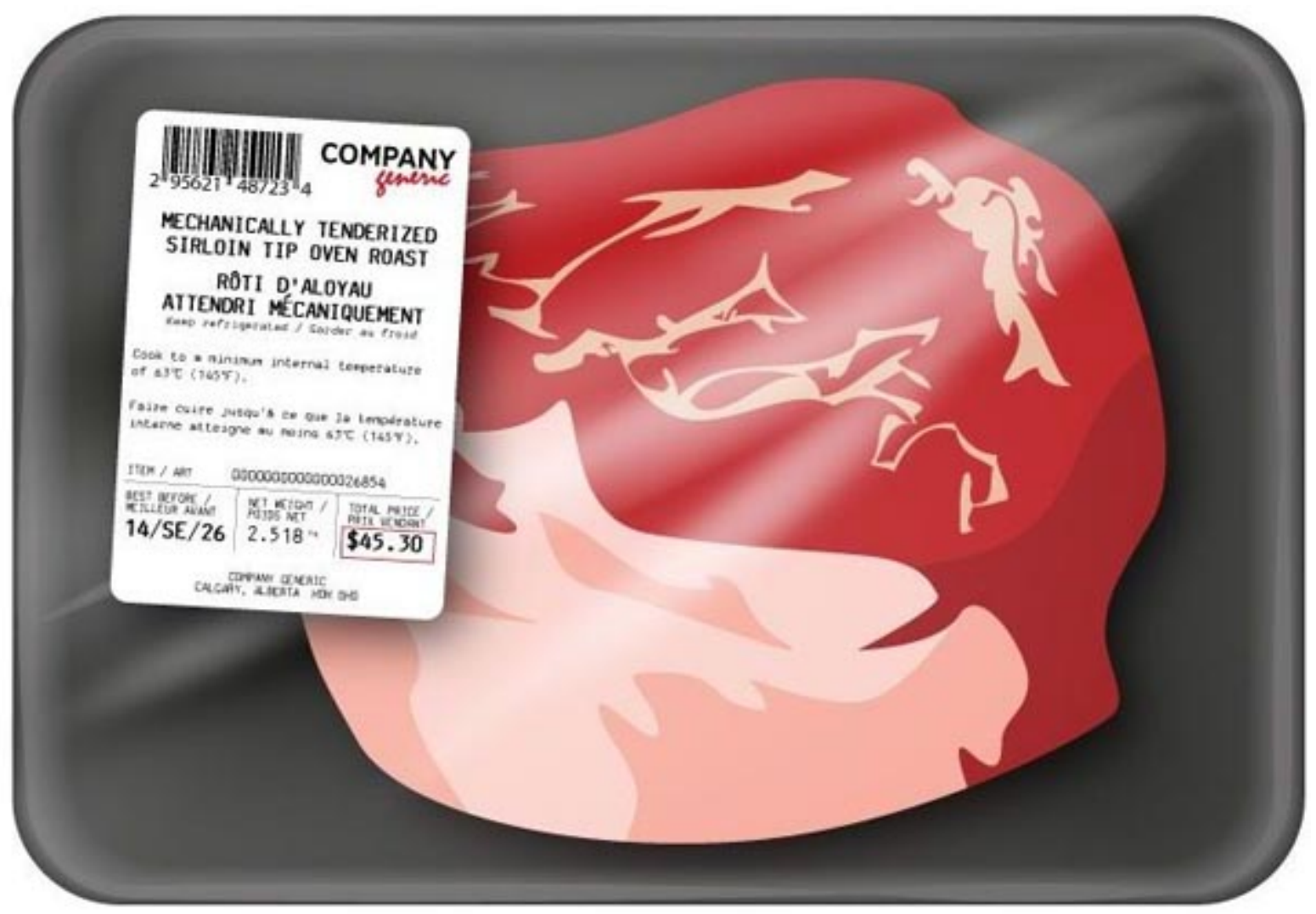

Figure 3: Percentage of participants by age group in BC, $2015(\mathrm{~N}=74)$

\section{Percentage of participants by age group in $\mathrm{BC}(\mathrm{N}=\mathbf{7 4})$}

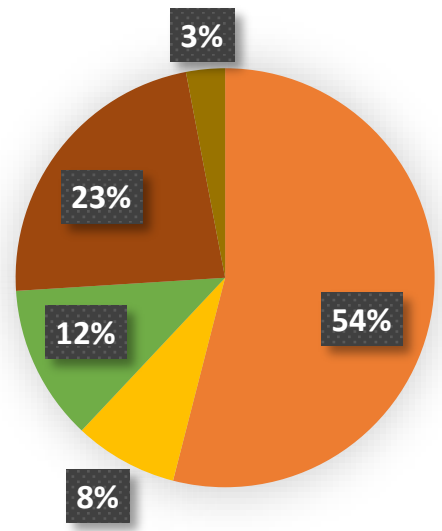

$$
\begin{aligned}
& \square \text { 18-30 years } \\
& \text { 31-40 years } \\
& \text { 41-50 years } \\
& \square 50 \text { years } \\
& \square \text { Other }
\end{aligned}
$$


Figure 4: Percentage of participants by gender in BC, 2015 (N=74)

\section{Percentage of participants by gender in $\mathrm{BC}(\mathrm{N}=\mathbf{7 4})$}

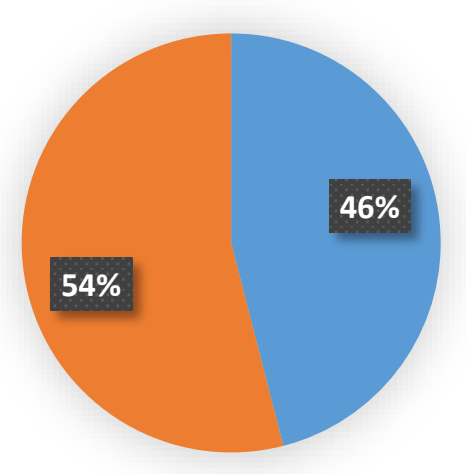

Male $\square$ Female

Figure 5: Percentage of participants by highest level of education in BC, 2015 (N=74)

\section{Percentage of participants by highest level of education in $B C(N=74)$}

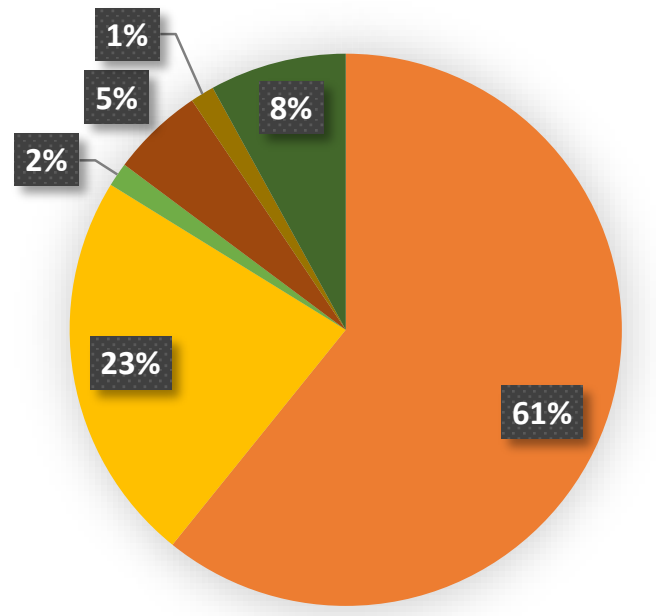

College or University with a degree or more

College or University with a diploma or certificate

- Currently in University without a completed degree

- High school

- Less than high school

- Some College or University but without a degree 
Figure 6: Percentage of participants by successful completion of a food safety course in BC, $2015(\mathrm{~N}=74)$

\section{Percentage of participants by completion of a food safety course in $\mathrm{BC}(\mathrm{N}=74)$}

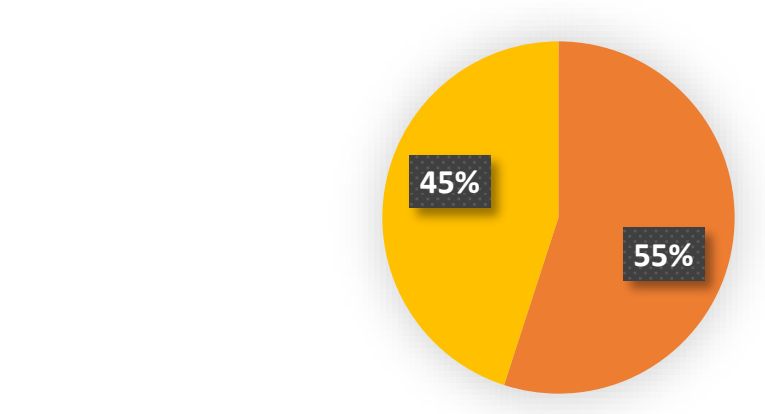

Figure 7: Percentage of participants by awareness of health risk associated with mechanically tenderized beef in BC, $2015(\mathrm{~N}=74)$

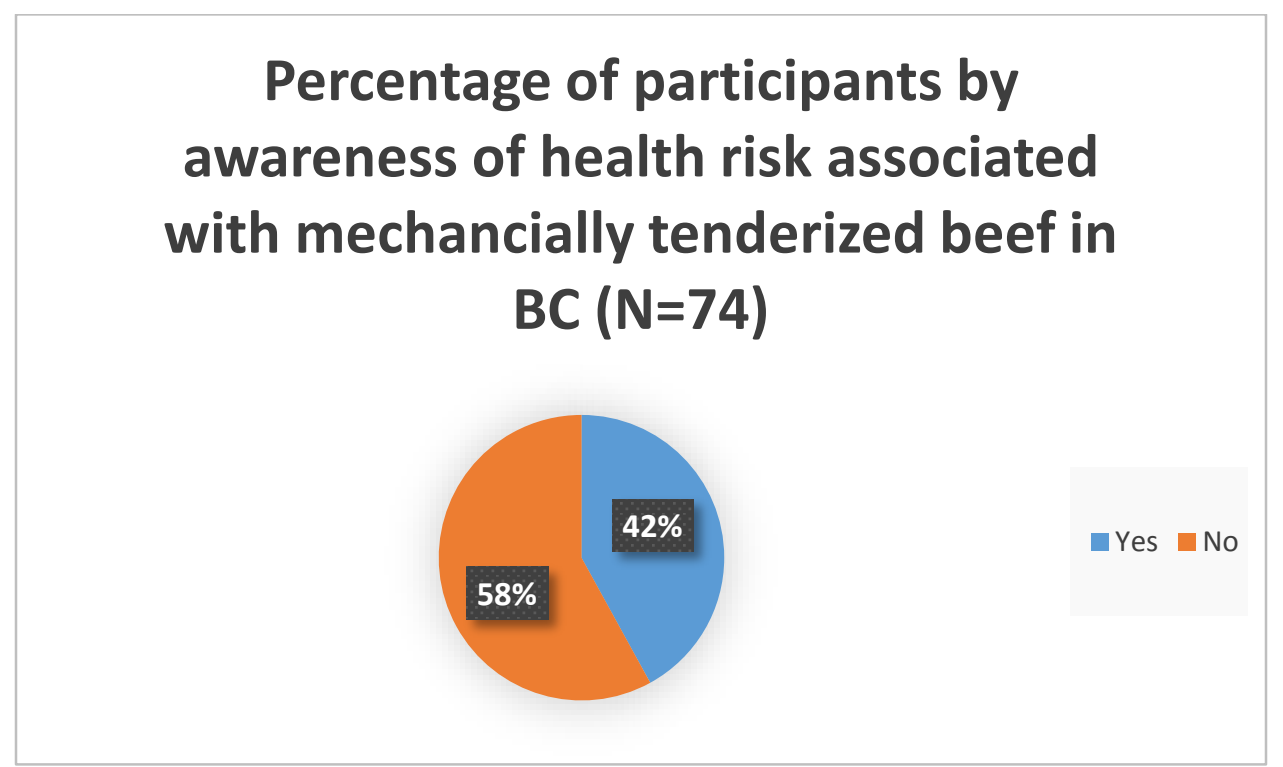


Figure 8: Percentage of participants willing to purchase mechanically tenderized beef in BC, $2015(\mathrm{~N}=74)$

\section{Percentage of participants willing to purchase mechanically tenderized beef in $\mathrm{BC}(\mathrm{N}=74)$}

\section{$10 \%$}

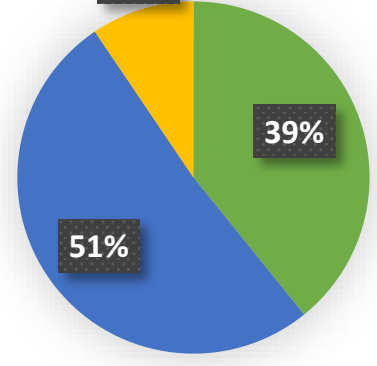

Figure 9: Percentage of participants by cooking practices in abiding with information on mechanically tenderized beef labels in BC, $2015(\mathrm{~N}=74)$

Percentage of participants with respect to following labeliing instructions on mechanically tenderized beef in $B C(N=74)$

$$
\text { - Yes } \text { - No }
$$

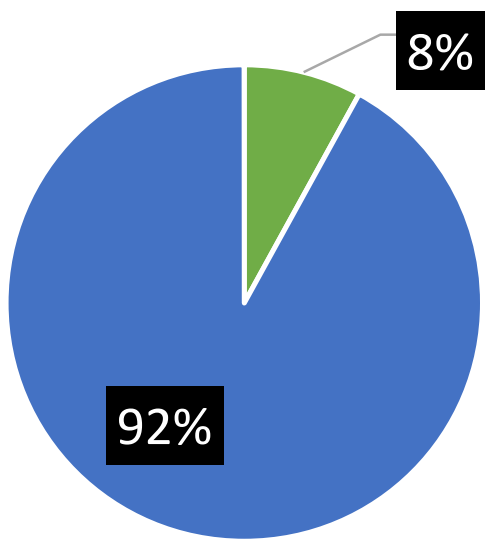


Figure 10: Percentage of cooking practices that abide with information provided on mechanically tenderized beef labels in BC, $2015(\mathrm{~N}=74)$

\section{Percentage of cooking practice components that abide with information on mechanically tenderized beef labels in BC $(N=74)$}
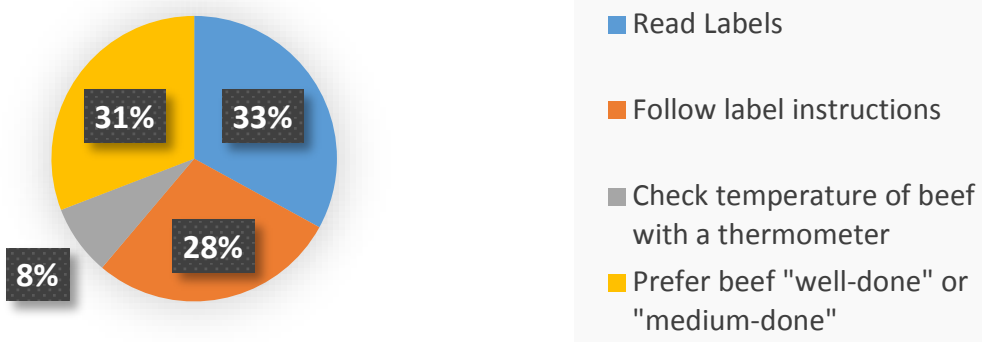

Figure 11: Percentage of cooking practices that involve flipping steak at least twice in accordance with mechanically tenderized beef labels in BC, $2015(\mathrm{~N}=69)$

\section{Percentage of cooking practices that involve flipping steak at least twice as specified on mechanically tenderized beef labels in BC $(\mathrm{N}=69)$}

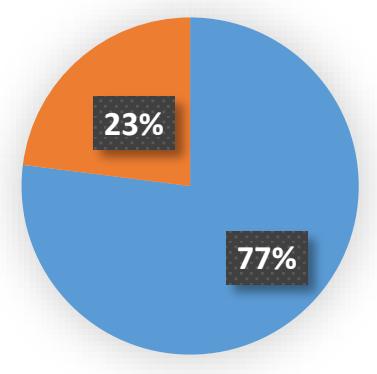


Figure 12: Percentage of participants by preferred method of receiving cooking information

\section{Percentage of participants by preferred method of receiving cooking instructions on beef in $\mathrm{BC}(\mathrm{N}=72)$}

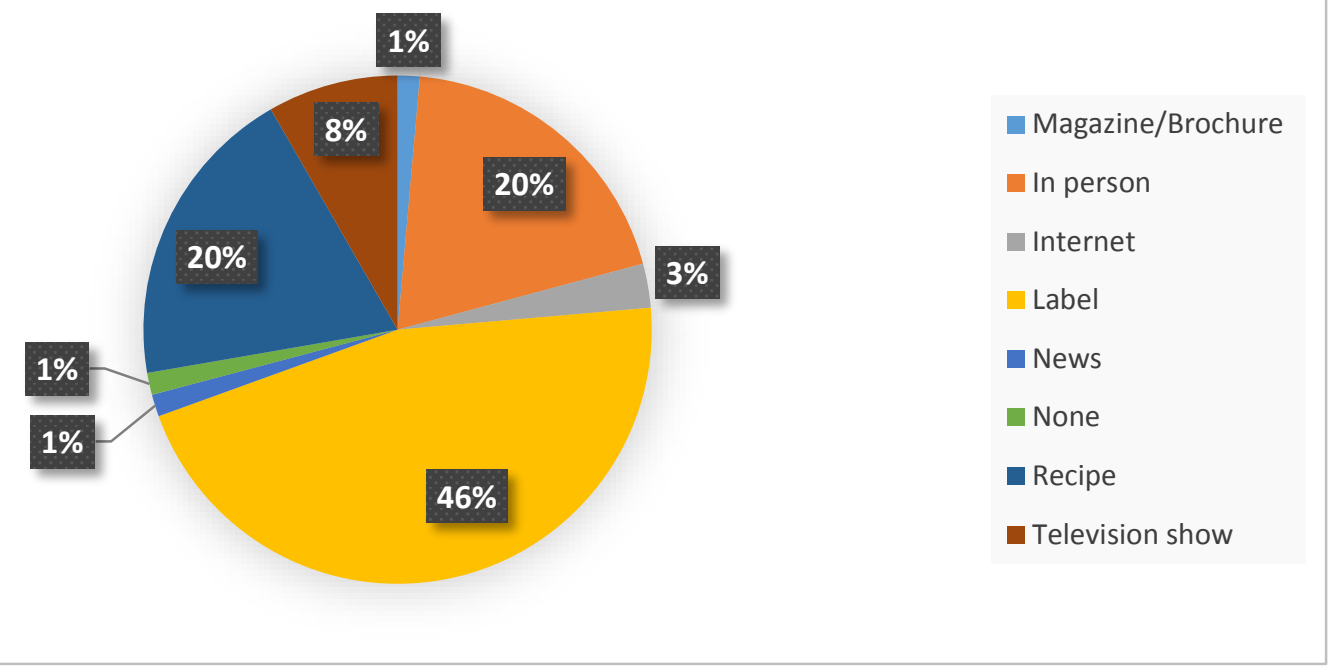

Figure 13: Percentage of respondents by preference of beef doneness

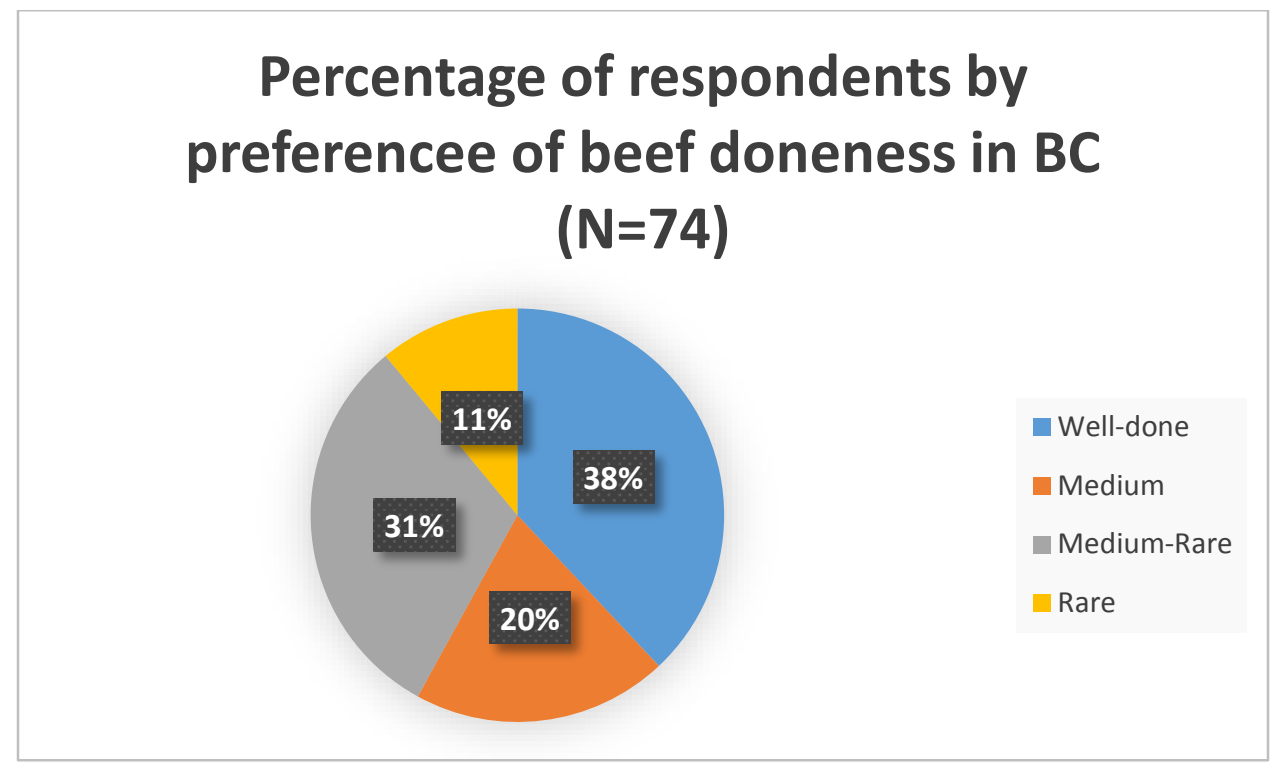


Figure 14: Association between age and label effectiveness in BC, $2015(\mathrm{~N}=72)$

Summary.

\begin{tabular}{||c||r|r|r|r|r|r|}
\hline \hline \multicolumn{1}{||c||}{} & \multicolumn{6}{c|}{ Cases } \\
\cline { 2 - 8 } & \multicolumn{2}{|c|}{ Valid } & \multicolumn{2}{c|}{ Missing } & \multicolumn{2}{c|}{ Total } \\
\cline { 2 - 8 } & $\mathrm{N}$ & Percent & $\mathrm{N}$ & Percent & $\mathrm{N}$ & Percent \\
\hline Age * Effective & 72 & $100.0 \%$ & 0 & $0.0 \%$ & 72 & $100.0 \%$ \\
\hline
\end{tabular}

Age ${ }^{\star}$ Effective [count, row $\%$, column \%, total \%].

\begin{tabular}{|c|c|c|c|}
\hline \multirow[b]{2}{*}{ Age } & \multicolumn{2}{|c|}{ Effective } & \multirow[b]{2}{*}{ Total } \\
\hline & No & Yes & \\
\hline \multirow[t]{4}{*}{$18-30$ years } & 39.00 & 1.00 & 40.00 \\
\hline & $97.50 \%$ & $2.50 \%$ & $100.00 \%$ \\
\hline & $57.35 \%$ & $25.00 \%$ & $55.56 \%$ \\
\hline & $54.17 \%$ & $1.39 \%$ & $55.56 \%$ \\
\hline \multirow[t]{4}{*}{$31-40$ years } & 6.00 & .00 & 6.00 \\
\hline & $100.00 \%$ & $.00 \%$ & $100.00 \%$ \\
\hline & $8.82 \%$ & $.00 \%$ & $8.33 \%$ \\
\hline & $8.33 \%$ & $.00 \%$ & $8.33 \%$ \\
\hline \multirow[t]{4}{*}{$41-50$ years } & 9.00 & .00 & 9.00 \\
\hline & $100.00 \%$ & $.00 \%$ & $100.00 \%$ \\
\hline & $13.24 \%$ & $.00 \%$ & $12.50 \%$ \\
\hline & $12.50 \%$ & $.00 \%$ & $12.50 \%$ \\
\hline \multirow[t]{4}{*}{50 years or older } & 14.00 & 3.00 & 17.00 \\
\hline & $82.35 \%$ & $17.65 \%$ & $100.00 \%$ \\
\hline & $20.59 \%$ & $75.00 \%$ & $23.61 \%$ \\
\hline & $19.44 \%$ & $4.17 \%$ & $23.61 \%$ \\
\hline \multirow[t]{4}{*}{ Total } & 68.00 & 4.00 & 72.00 \\
\hline & $94.44 \%$ & $5.56 \%$ & $100.00 \%$ \\
\hline & $100.00 \%$ & $100.00 \%$ & $100.00 \%$ \\
\hline & $94.44 \%$ & $5.56 \%$ & $100.00 \%$ \\
\hline
\end{tabular}

Chi-square tests.

\begin{tabular}{||l||r|r|r||}
\hline \hline Statistic & Value & $d f$ & Asymp. Sig. (2-tailed) \\
\hline Pearson Chi-Square & 6.33 & 3 & .097 \\
Likelihood Ratio & 5.70 & 3 & .127 \\
N of Valid Cases & 72 & & \\
\hline
\end{tabular}


Figure 15: Association between gender and label effectiveness in BC, 2015 (N=74)

Summary.

\begin{tabular}{||r|r|r|r|r|r|r|}
\hline \hline \multicolumn{1}{||c||}{} & \multicolumn{6}{c|}{ Cases } \\
\cline { 2 - 8 } & \multicolumn{2}{|c|}{ Valid } & \multicolumn{2}{c|}{ Missing } & \multicolumn{2}{c|}{ Total } \\
\cline { 2 - 8 } & $\mathrm{N}$ & Percent & $\mathrm{N}$ & Percent & $\mathrm{N}$ & Percent \\
\hline Gender * Effective & 74 & $100.0 \%$ & 0 & $0.0 \%$ & 74 & $100.0 \%$ \\
\hline
\end{tabular}

Gender * Effective [count, row \%, column \%, total \%].

\begin{tabular}{||r||r|r|r||}
\hline \hline \multirow{3}{*}{ Gender } & \multicolumn{2}{|c||}{ Effective } & \multicolumn{1}{c||}{} \\
\cline { 2 - 3 } Female & No & Yes & \multicolumn{1}{c|}{ Total } \\
\hline & 98.00 & 2.00 & 40.00 \\
& $55.00 \%$ & $5.00 \%$ & $100.00 \%$ \\
& $55.88 \%$ & $33.33 \%$ & $54.05 \%$ \\
\hline Male & $51.35 \%$ & $2.70 \%$ & $54.05 \%$ \\
& 30.00 & 4.00 & 34.00 \\
& $88.24 \%$ & $11.76 \%$ & $100.00 \%$ \\
& $44.12 \%$ & $66.67 \%$ & $45.95 \%$ \\
\hline Total & $40.54 \%$ & $5.41 \%$ & $45.95 \%$ \\
& 68.00 & 6.00 & 74.00 \\
& $91.89 \%$ & $8.11 \%$ & $100.00 \%$ \\
& $100.00 \%$ & $100.00 \%$ & $100.00 \%$ \\
& $91.89 \%$ & $8.11 \%$ & $100.00 \%$ \\
\hline
\end{tabular}

Chi-square tests.

\begin{tabular}{||l||r|r|r|r|r||}
\hline \hline Statistic & Value & $d f$ & Asymp. Sig. (2-tailed) & Exact Sig. (2-tailed) & Exact Sig. (1-tailed) \\
\hline Pearson Chi-Square & 1.13 & 1 & .288 & & \\
Likelihood Ratio & 1.14 & 1 & .287 & & \\
Fisher's Exact Test & & & & .407 & .263 \\
Continuity Correction & .40 & 1 & .525 & & \\
N of Valid Cases & 74 & & & & \\
\hline
\end{tabular}


Figure 16: Association between highest level of education and label effectiveness in BC, $2015(\mathrm{~N}=74)$

Summary.

\begin{tabular}{||c||r|r|r|r|r|r|}
\hline \hline \multicolumn{1}{||c||}{} & \multicolumn{6}{c|}{ Cases } \\
\cline { 2 - 8 } & \multicolumn{2}{|c|}{ Valid } & \multicolumn{2}{c|}{ Missing } & \multicolumn{2}{|c|}{ Total } \\
\cline { 2 - 8 } & $\mathrm{N}$ & Percent & $\mathrm{N}$ & Percent & $\mathrm{N}$ & Percent \\
\hline Education * Effective & 74 & $100.0 \%$ & 0 & $0.0 \%$ & 74 & $100.0 \%$ \\
\hline
\end{tabular}

Education * Effective [count, row \%, column \%, total \%].

\begin{tabular}{|c|c|c|c|}
\hline \multirow[b]{2}{*}{ Education } & \multicolumn{2}{|c|}{ Effective } & \multirow[b]{2}{*}{ Total } \\
\hline & No & Yes & \\
\hline College or University with a degree or more & $\begin{array}{r}41.00 \\
91.11 \% \\
60.29 \% \\
55.41 \%\end{array}$ & $\begin{array}{r}4.00 \\
8.89 \% \\
66.67 \% \\
5.41 \%\end{array}$ & $\begin{array}{r}45.00 \\
100.00 \% \\
60.81 \% \\
60.81 \%\end{array}$ \\
\hline College or University with a diploma or certificate & $\begin{array}{r}17.00 \\
100.00 \% \\
25.00 \% \\
22.97 \%\end{array}$ & $\begin{array}{r}.00 \\
.00 \% \\
.00 \% \\
.00 \%\end{array}$ & $\begin{array}{r}17.00 \\
100.00 \% \\
22.97 \% \\
22.97 \%\end{array}$ \\
\hline Currently in University without a completed degree & $\begin{array}{r}1.00 \\
100.00 \% \\
1.47 \% \\
1.35 \%\end{array}$ & $\begin{array}{r}.00 \\
.00 \% \\
.00 \% \\
.00 \%\end{array}$ & $\begin{array}{r}1.00 \\
100.00 \% \\
1.35 \% \\
1.35 \%\end{array}$ \\
\hline High school & $\begin{array}{r}4.00 \\
100.00 \% \\
5.88 \% \\
5.41 \%\end{array}$ & $\begin{array}{r}.00 \\
.00 \% \\
.00 \% \\
.00 \%\end{array}$ & $\begin{array}{r}4.00 \\
100.00 \% \\
5.41 \% \\
5.41 \%\end{array}$ \\
\hline Less than high school & $\begin{array}{r}.00 \\
.00 \% \\
.00 \% \\
.00 \%\end{array}$ & $\begin{array}{r}1.00 \\
100.00 \% \\
16.67 \% \\
1.35 \%\end{array}$ & $\begin{array}{r}1.00 \\
100.00 \% \\
1.35 \% \\
1.35 \%\end{array}$ \\
\hline Some College or University but without a degree & $\begin{array}{r}5.00 \\
83.33 \% \\
7.35 \% \\
6.76 \%\end{array}$ & $\begin{array}{r}1.00 \\
16.67 \% \\
16.67 \% \\
1.35 \%\end{array}$ & $\begin{array}{r}6.00 \\
100.00 \% \\
8.11 \% \\
8.11 \%\end{array}$ \\
\hline Total & $\begin{array}{r}68.00 \\
91.89 \% \\
100.00 \% \\
91.89 \%\end{array}$ & $\begin{array}{r}6.00 \\
8.11 \% \\
100.00 \% \\
8.11 \%\end{array}$ & $\begin{array}{r}74.00 \\
100.00 \% \\
100.00 \% \\
100.00 \%\end{array}$ \\
\hline
\end{tabular}

Chi-square tests.

\begin{tabular}{||l||r|r|r||}
\hline \hline Statistic & Value & $d f$ & Asymp. Sig. (2-tailed) \\
\hline Pearson Chi-Square & 13.90 & 5 & .016 \\
Likelihood Ratio & 9.24 & 5 & .100 \\
N of Valid Cases & 74 & & \\
\hline
\end{tabular}


Figure 17: Association between successful completion of a food safety course and label effectiveness in BC, $2015(\mathrm{~N}=74)$

Summary.
\begin{tabular}{|l|r|r|r|r|r|r|}
\hline \multirow{1}{*}{} & \multicolumn{6}{|c|}{ Cases } \\
\cline { 2 - 8 } & \multicolumn{2}{|c|}{ Valid } & \multicolumn{2}{c|}{ Missing } & \multicolumn{2}{c|}{ Total } \\
\cline { 2 - 8 } & $\mathrm{N}$ & Percent & $\mathrm{N}$ & Percent & $\mathrm{N}$ & Percent \\
\hline Food_Safety_Course *Effective & 74 & $100.0 \%$ & 0 & $0.0 \%$ & 74 & $100.0 \%$ \\
\hline
\end{tabular}

Food_Safety_Course * Effective [count, row \%, column \%, total \%].

\begin{tabular}{|c|c|c|c|}
\hline \multirow[b]{2}{*}{ Food Safety Course } & \multicolumn{2}{|c|}{ Effective } & \multirow[b]{2}{*}{ Total } \\
\hline & No & Yes & \\
\hline \multirow[t]{4}{*}{ No } & 36.00 & 5.00 & 41.00 \\
\hline & $87.80 \%$ & $12.20 \%$ & $100.00 \%$ \\
\hline & $52.94 \%$ & $83.33 \%$ & $55.41 \%$ \\
\hline & $48.65 \%$ & $6.76 \%$ & $55.41 \%$ \\
\hline \multirow[t]{4}{*}{ Yes } & 32.00 & 1.00 & 33.00 \\
\hline & $96.97 \%$ & $3.03 \%$ & $100.00 \%$ \\
\hline & $47.06 \%$ & $16.67 \%$ & $44.59 \%$ \\
\hline & $43.24 \%$ & $1.35 \%$ & $44.59 \%$ \\
\hline \multirow[t]{4}{*}{ Total } & 68.00 & 6.00 & 74.00 \\
\hline & $91.89 \%$ & $8.11 \%$ & $100.00 \%$ \\
\hline & $100.00 \%$ & $100.00 \%$ & $100.00 \%$ \\
\hline & $91.89 \%$ & $8.11 \%$ & $100.00 \%$ \\
\hline
\end{tabular}

Chi-square tests.

\begin{tabular}{|l||r|r|r|r|r||}
\hline \hline Statistic & Value & $d f$ & Asymp. Sig. (2-tailed) & Exact Sig. (2-tailed) & Exact Sig. (1-tailed) \\
\hline Pearson Chi-Square & 2.06 & 1 & .151 & & \\
Likelihood Ratio & 2.28 & 1 & .131 & & \\
Fisher's Exact Test & & & & .217 & .158 \\
Continuity Correction & 1.01 & 1 & .314 & & \\
N of Valid Cases & 74 & & & & \\
\hline
\end{tabular}


Figure 18: Association between awareness of risk associated with mechanically tenderized beef and label effectiveness in BC, $2015(\mathrm{~N}=74)$

Summary.

\begin{tabular}{||l||r|r|r|r|r|r|}
\hline \hline \multicolumn{1}{||c||}{} & \multicolumn{6}{c|}{ Cases } \\
\cline { 2 - 7 } & \multicolumn{2}{|c|}{ Valid } & \multicolumn{2}{c|}{ Missing } & \multicolumn{2}{c|}{ Total } \\
\cline { 2 - 7 } & $\mathrm{N}$ & Percent & $\mathrm{N}$ & Percent & $\mathrm{N}$ & Percent \\
\hline Awareness_of_Risk * Effective & 74 & $100.0 \%$ & 0 & $0.0 \%$ & 74 & $100.0 \%$ \\
\hline
\end{tabular}

Awareness_of_Risk * Effective [count, row \%, column \%, total \%].

\begin{tabular}{|c|c|c|c|}
\hline \multirow[b]{2}{*}{ Awareness_of_Risk } & \multicolumn{2}{|c|}{ Effective } & \multirow[b]{2}{*}{ Total } \\
\hline & No & Yes & \\
\hline \multirow[t]{4}{*}{ No } & 40.00 & 3.00 & 43.00 \\
\hline & $93.02 \%$ & $6.98 \%$ & $100.00 \%$ \\
\hline & $58.82 \%$ & $50.00 \%$ & $58.11 \%$ \\
\hline & $54.05 \%$ & $4.05 \%$ & $58.11 \%$ \\
\hline \multirow[t]{4}{*}{ Yes } & 28.00 & 3.00 & 31.00 \\
\hline & $90.32 \%$ & $9.68 \%$ & $100.00 \%$ \\
\hline & $41.18 \%$ & $50.00 \%$ & $41.89 \%$ \\
\hline & $37.84 \%$ & $4.05 \%$ & $41.89 \%$ \\
\hline \multirow[t]{4}{*}{ Total } & 68.00 & 6.00 & 74.00 \\
\hline & $91.89 \%$ & $8.11 \%$ & $100.00 \%$ \\
\hline & $100.00 \%$ & $100.00 \%$ & $100.00 \%$ \\
\hline & $91.89 \%$ & $8.11 \%$ & $100.00 \%$ \\
\hline
\end{tabular}

Chi-square tests.

\begin{tabular}{|l||r|r|r|r|r||}
\hline Statistic & Value & $d f$ & Asymp. Sig. (2-tailed) & Exact Sig. (2-tailed) & Exact Sig. (1-tailed) \\
\hline Pearson Chi-Square & .18 & 1 & .675 & & \\
Likelihood Ratio & .17 & 1 & .676 & & \\
Fisher's Exact Test & & & & .696 & .496 \\
Continuity Correction & .00 & 1 & 1.000 & & \\
N of Valid Cases & 74 & & & & \\
\hline
\end{tabular}


Figure 19: Association between preferred method of receiving cooking information and label effectiveness in $\mathrm{BC}, 2015(\mathrm{~N}=72)$

\begin{tabular}{|c|c|c|c|c|c|c|}
\hline & \multicolumn{6}{|c|}{ Cases } \\
\hline & \multicolumn{2}{|c|}{ Valid } & \multicolumn{2}{|c|}{ Missing } & \multicolumn{2}{|c|}{ Total } \\
\hline & $\mathrm{N}$ & Percent & $\mathrm{N}$ & Percent & $\mathrm{N}$ & Percent \\
\hline Preferred_Method * Effective & 72 & $100.0 \%$ & 0 & $0.0 \%$ & 72 & $100.0 \%$ \\
\hline
\end{tabular}

Preferred_Method * Effective [count, row \%, column \%, total \%].

\begin{tabular}{|c|c|c|c|}
\hline \multirow[b]{2}{*}{ Preferred_Method } & \multicolumn{2}{|c|}{ Effective } & \multirow[b]{2}{*}{ Total } \\
\hline & No & Yes & \\
\hline \multirow[t]{4}{*}{ No } & 36.00 & 3.00 & 39.00 \\
\hline & $92.31 \%$ & $7.69 \%$ & $100.00 \%$ \\
\hline & $54.55 \%$ & $50.00 \%$ & $54.17 \%$ \\
\hline & $50.00 \%$ & $4.17 \%$ & $54.17 \%$ \\
\hline \multirow[t]{4}{*}{ Yes } & 30.00 & 3.00 & 33.00 \\
\hline & $90.91 \%$ & $9.09 \%$ & $100.00 \%$ \\
\hline & $45.45 \%$ & $50.00 \%$ & $45.83 \%$ \\
\hline & $41.67 \%$ & $4.17 \%$ & $45.83 \%$ \\
\hline \multirow[t]{4}{*}{ Total } & 66.00 & 6.00 & 72.00 \\
\hline & $91.67 \%$ & $8.33 \%$ & $100.00 \%$ \\
\hline & $100.00 \%$ & $100.00 \%$ & $100.00 \%$ \\
\hline & $91.67 \%$ & $8.33 \%$ & $100.00 \%$ \\
\hline
\end{tabular}

Chi-square tests.

\begin{tabular}{||l||r|r|r|r|r||}
\hline \hline Statistic & Value & $d f$ & Asymp. Sig. (2-tailed) & Exact Sig. (2-tailed) & Exact Sig. (1-tailed) \\
\hline Pearson Chi-Square & .05 & 1 & .831 & & \\
Likelihood Ratio & .05 & 1 & .831 & & \\
Fisher's Exact Test & & & & & \\
Continuity Correction & .00 & 1 & 1.000 & & \\
N of Valid Cases & 72 & & & & \\
\hline
\end{tabular}


Appendix 3

Questionnaire (with a consent component)

\section{Survey: Labeling Effectiveness of Beef}

Please answer all of the following questions if you cook beef, reside in British Columbia, and.are above the age of 18 years.

* Required

I understand that my participation is voluntary and the information collected will remain confidential. I agree to participate in this study. *

o Г Yes

1. What is your age group?
o 18-30 years
o $31-40$ years
o $41-50$ years
- 51 years or older
o $C$ Other

2. What is your gender?
- $\mathrm{C}$ Male
- $\mathrm{C}$ Female
- $\mathrm{C}$ Other

3. What is the highest level of education you have completed?
- $C$ Less than high school
o High school
- Some College or University but without a degree
- College or University with a diploma or certificate
- C College or University with a degree or more
o $\mathrm{C}$ Other:

4. Have you successfully completed a food safety course (e.g. FOODSAFE, MarketSafe, SlaughterSafe)?

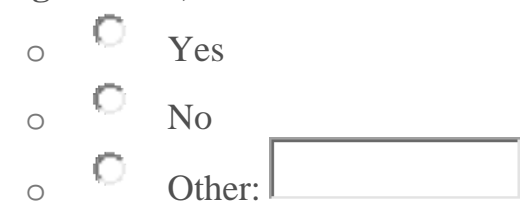

5. Are you aware of the E. coli food poisonings caused by XL Foods Inc. beef products in 2012? 


$\begin{array}{lll}0 & C & \text { Yes } \\ 0 & C & \text { No } \\ 0 & C & \text { Unsure }\end{array}$

6. Mechanically tenderized beef is uncooked, intact beef that has been made tender through piercing it with instruments (e.g. needles, blades) or by adding a tenderizing solution (e.g. marinade solution). Is there a health risk associated with this type of beef?
- $C$ Yes
- $\mathrm{No}$
- $\mathrm{C}$ Unsure

7. Would you purchase beef knowing that is has been mechanically tenderized (e.g. pierced with needles, blades, or has a tenderizing solution added to it)?
- $\mathrm{C}$ Yes
- $C$ No
o $\mathrm{O}$ Other:

8. Do you read labels on the packaging of beef?
- $C$ Yes
- $\mathrm{C}$ No
o $\mathrm{O}$ Other:

9. Do you follow the cooking instructions provided on the label of beef?
- $C$ Yes
o $C$ No
o $\mathrm{C}$ Other:

10. Do you check the temperature of beef with a thermometer upon cooking it?
- $\mathrm{C}$ Yes
- $C$ No
o $\mathrm{O}$ Other:

11. How do you like your beef done?
- $C$ Rare
- $C$ Medium-rare
- $\mathrm{C}$ Medium
- $C$ Well-done
o $\mathrm{C}$ Other:

12. How many times do you flip or turn over steak when you cook it? 
13. What is your preferred method for receiving instructions/information on safely cooking beef?
- Label
- $\mathrm{C}$ Brochure/Magazine
o In person (from a butcher, retailer, or health professional)
o Television show (e.g. cooking show)
- $\mathrm{C}$ Recipe
o $\mathrm{C}$ Other: 